\title{
Atg5 knockdown induces age-dependent cardiomyopathy which can be rescued by repeated remote ischemic conditioning
}

\author{
Fangfei Wang ${ }^{1}$ - Quan $\mathrm{He}^{1} \cdot$ Zhiqian $\mathrm{Gao}^{1}$ - Andrew N. Redington ${ }^{1}$ (])
}

Received: 8 February 2021 / Accepted: 15 July 2021 / Published online: 28 July 2021

c) Springer-Verlag GmbH Germany, part of Springer Nature 2021

\begin{abstract}
Altered autophagy is implicated in several human cardiovascular diseases. Remote ischemic conditioning (RIC) is cardioprotective in multiple cardiovascular injury models and modifies autophagy signaling, but its effect in cardiomyopathy induced by gene manipulation has not been reported. To investigate the cardiac effects of chronically reduced autophagy as a result of Atg5 knockdown and assess whether RIC can rescue the phenotype. Atg5 knockdown was induced with tamoxifen for 14 days in cardiac-specific conditional Atg 5 flox mice. Autophagy proteins and cardiac function were evaluated by Western blot and echocardiography, respectively. RIC was induced by cyclical hindlimb ischemia and reperfusion using a tourniquet. RIC or sham procedure was performed daily during tamoxifen induction and, in separate experiments, chronically 3 times per week for 8 weeks. Cardiac responses were assessed by end of the study. Cardiac-specific knockdown of $\operatorname{Atg} 5$ reduced protein levels by $70 \%$ and was associated with a significant increase in mTOR, a reduction of LC3-II and increased upstream autophagy proteins including LC3-I, P62, and Beclin. The changes in biochemical markers were associated with development of an age-related cardiomyopathy during the 17-month follow-up indicated by increased heart weight body weight ratio, progressive decline in cardiac function, and premature death. RIC increased cardiac ATG5 and rescued some of the Atg5 knockdown-induced cardiomyopathy phenotype and associated morphological remodeling. We conclude that cardiac-specific Atg5 knockdown leads to the development of age-related cardiomyopathy. RIC reverses the molecular and structural phenotype when administered both acutely and chronically.
\end{abstract}

Keywords Inducible gene ablation $\cdot$ Cardiac function $\cdot$ Autophagy $\cdot$ Preconditioning

$\begin{array}{ll}\text { Abbreviations } \\ \text { ATG5 } & \text { Autophagy related protein } 5 \\ \text { PAS } & \text { Pre-autophagosomal structure } \\ \text { RIC } & \text { Remote ischemic conditioning } \\ \text { MCSA } & \text { Myocyte cross section area } \\ \text { RT } & \text { Room temperature } \\ \text { EF } & \text { Ejection fraction } \\ \text { FS } & \text { Fractional shortening } \\ \text { LVIDD } & \text { Left ventricular internal diameter end diastole } \\ \text { LVIDS } & \text { Left ventricular internal diameter end systole }\end{array}$

Fangfei Wang and Quan He have contributed equally.

Andrew N. Redington

Andrew.redington@cchmc.org

1 The Heart Institute, Cincinnati Children's Hospital Medical Center, 3333 Burnet Ave., Cincinnati, OH 45229, USA

\section{Introduction}

Autophagy is an evolutionary conserved and tightly regulated process that facilitates intracellular digestion and recycling of dysfunctional organelles and accumulated protein aggregates. Accumulation of unfolded intracellular proteins or damaged organelles may cause genomic instability and cell death leading to premature aging, cancer, and tissue degeneration. Excessive autophagy can cause disease, such as X-linked myopathy [1], and cell death due to excessive self-consumption of cellular contents [2], while reduced autophagy has been associated with many age-related and chronic human diseases [3].

Autophagy related 5 (APG/ATG5) is a key protein that, in humans, is encoded by the ATG5 gene located on chromosome $6 \mathrm{q} 21$. The protein is involved in the nucleation of the phagophor, a small cup-like membrane precursor formed upon induction of autophagy as part of an intricate membrane complex which is called the pre-autophagosomal structure (PAS). PAS is composed of membrane-associated 
active autophagy proteins including Beclin. ATG5 forms a complex with ATG12 and ATG16 to catalyze ligation of LC3-I and phosphotidylethanolamine on the phagophore converting LC3-I to LC3-II on the phagophor membrane [4]. The ATG5-ATG12-ATG16 complex also directs itself to the phagophor membrane, becoming a docking site for adaptor proteins leading to cargo protein degradation. After docking of ubiquitilized cargo proteins via P62/SQSTM1 [5], the phagophore is enclosed to form the autophagosome. The cargo proteins are digested and recycled in the autolysosome, which results from the fusion of the autophagosome and lysosomes.

Accumulating evidence suggests that ATG5 is involved in several human diseases, including cardiomyopathy. Alteration of ATG5 expression has been found in neurodegenerative diseases [6-8] and type II diabetes [9, 10], and ATG5 polymorphisms have been associated with development of coronary artery disease and acute myocardial infarction [11], autoimmune diseases including system lupus erythematosus [12-15], sepsis [16], Crohn's disease [17], and cancer [18].

In mice, overexpression of Atg5 activates autophagy, increases insulin sensitivity, and ultimately results in extended lifespan [19]. Cardiac-specific knock out of Atg5 induces a cardiomyopathy characterized by collapsed mitochondria, disorganized sarcomere structure, increased left ventricular dimension, and reduced cardiac function and early death [20]. ATG5 is also important in the development of cardiac hypertrophy. Genetic manipulation of the immunoproteasome catalytic $\beta 5$ i subunit which targets to the ubiquitination and degradation of ATG5 was a crucial pathogenic step in a model of pressure overload-induced cardiac hypertrophy. The hypertrophic response in this model was increased by cardiac-specific overexpression of $\beta 5 i$ but abrogated by deficiency of $\beta 5 i$ [21].

Remote ischemic conditioning (RIC), induced by 4 cycles of 5 min occlusion and $5 \mathrm{~min}$ reperfusion of a limb, has been demonstrated cardioprotective in animal models and clinical conditions such as ischemia/reperfusion injury [22], ventricular remodeling after myocardial infarction [23] and septic cardiomyopathy induced by lipopolysaccharide [24], and doxorubicin-induced cardiotoxicity in mice [25]. We have previously demonstrated [26] that RIC, both when administered acutely and chronically, is a strong pro-autophagy stimulus via suppression of mammalian target of rapamycin (mTOR), a known negative regulator of autophagy, which leads to improved myocardial function in a mouse MI/heart failure model. However, despite consistently encouraging preclinical experimental, and 'proof-of-principle' clinical studies in highly selected patient groups, the translation of RIC in phase III clinical trials has been disappointing [27, 28]. Multiple factors for lack of clinical effect have been suggested, including older patient age, the effect of comorbidities (e.g. diabetes, hyperlipidemia) and the concomitant use of drugs that may block the RIC effect or themselves induce a conditioned' state $[29,30]$. These factors are clearly less relevant in preclinical experiments with animals, and such factors may not be at play in younger patients with different therapeutic profiles and comorbities. Children and young adults with inherited cardiomyopathies, or toxin-related cardiomyopathy may fall into such a category and we, and others, have shown promising effects of RIC in experimental models of LPS-induced myocardial dysfunction [24], and Doxorubicin-induced cardiomyopathy [25, 31, 32], for example.

Whether RIC protects the heart in cardiomyopathy induced by gene manipulation has not been tested. Consequently, we created inducible cardiac-specific Atg5 knockdown mice to address the effects of RIC on cardiomyopathy induced by genetic modification.

\section{Methods}

Mice bearing Atg5flox allele (Atg $\left.5^{\operatorname{lox} P / l o x P}\right)$ in which Atg5 exon 3 is flanked by two loxP sequences originally produced by Mizushima group [33], were obtained from RIKEN BRC (Tsukuba, Japan). Tamoxifen-inducible and cardiac-specific Cre recombinase knock-in transgenic mice ( $\alpha$-MHCMerCreMer), originally created by Dr. Molkentin group [34], were kindly provided by Dr. Jeffrey Robbins within our institution.

\section{Creation of cardiac-specific Atg5 knockdown mice}

Atg $5^{\text {loxP/loxP }}$ mice were crossed with $\alpha$-MHC-MerCreMer transgenic mouse, only Atg $5^{\text {loxP/loxP }} / \alpha-M H C-M e r C r e M e r$ mice with heterogenous Cre $\left(\right.$ Atg $5^{\text {loxP } / l o x P} / \alpha-M H C$ MerCreMer, Atg $5^{\operatorname{loxP} P l o x P} \mathrm{Cre}$ ) were used for this study as a previous study showed that high level myocardial expression of $\mathrm{Cre}$-recombinase resulting in dilated cardiomyopathy [35]. Atg 5 knockdown was induced by feeding tamoxifen containing chow for 14 days. This reduced cardiac ATG5 by about 70\% comparing with $\mathrm{Cre}$ negative littermates.

\section{Animal experiments}

Animal experimental procedures were defined in animal protocol IACUC 2018-0026 which was approved by the Institutional Animal Care and Use Committees of the Cincinnati Children's Hospital Medical Center in accordance with the Animal Welfare Act (AWA) and PHS Policy on Humane Care and Use of Laboratory Animals. Mice were housed in a fully equipped animal facility on a $12 \mathrm{~h}$ dark/ light cycle with free access to food and water ad libitum. The primary outcome of measure was ATG5 protein alteration. Other autophagy protein and cardiac physical/functional 
changes were considered as secondary endpoints. Experimental design is followed the previous published "Practical guidelines for rigor and reproducibility in preclinical and clinical studies on cardioprotection" [36].

To induce Cre recombinase mediated Atg5 knockdown, mice were switched to tamoxifen diet TD.130860 containing $0.4 \mathrm{~g} / \mathrm{kg}$ tamoxifen from ENVIGO (Madison, WI) for 14 days. To evaluate autophagy proteins, adult ( $8-9$ weeks) Atg $5^{\operatorname{loxP} / l o x P}$ Cre mice were fed tamoxifen diet for 14 days and switched back to regular chow for another 14 days. Mice without $\mathrm{Cre}\left(\mathrm{Atg} 5^{{ }^{\operatorname{loxP} P l o x P}} \mathrm{Cre}^{-}, \mathrm{Atg} 5^{\operatorname{lox} P / \operatorname{lox} P}\right)$ were served as controls. Separate groups of age-matched mice with both genotypes were fed regular chow for all the experimental period to serve as controls. At the end of the study period mice were euthanized, and the heart was harvested for autophagy protein assessment by Western blotting.

For survival experiments, adult Atg $5^{\operatorname{loxP} / / o x P} \mathrm{Cre}$ and Atg $5^{\operatorname{lox} P / \operatorname{lox} P}$ mice were treated with/without tamoxifen diet for 14 days and cardiac function was monitored till 17 -month-old. Survival rate was calculated. The surviving mice were euthanized at end of the experiment, and heart was harvested for heart weight body weight ratio.

For remote ischemic conditioning (RIC) intervention experiments, adult $\mathrm{Atg} 5^{\text {loxP/loxP }} \mathrm{Cre}$ mice were fed tamoxifen diet for 14 days and the food was switched back regular chow. Two RIC intervention protocols were performed to test the early acute and late chronic effects (Fig. 1). (i) Early acute RIC: during Atg5 knocking down, starting at the same time as tamoxifen induction, RIC was performed once a day for 7 days as study from our laboratory showed that daily RIC is superior over one time pre- or post-RIC to potentiate LPS-induced mortality in mice[24]. Cardiac function was evaluated at 28 days after tamoxifen induction, and animals were euthanized after echocardiography. The heart was harvested after injection of $1 \mathrm{mM} \mathrm{KCl}$ to rest the heart at relaxation and sliced into 3 pieces transversely after removal of the atriums, the middle section was embedded in optimal cutting temperature (OCT) compound for histology analysis. The remainder was homogenized and prepared for autophagy protein analysis by Western blot. (ii) Late chronic RIC was performed 2 months after Atg 5 knockdown and continued 3 times/week for 8 weeks. The animals were followed up to 6 months till 12-month-old and cardiac function was determined by echocardiography. By end of the experiment, heart tissue was harvested for autophagy protein assays.

Remote ischemic conditioning was performed with a custom tourniquet to induce 4 cycles of 5 min hindlimb ischemia followed by reperfusion. Ischemia and subsequent reperfusion was confirmed with a Dopplex D900 from ArjoHuntleigh (Addison, IL). RIC was performed on one hindlimb for logistic reasons in this chronic model. Although there is a report showed that acute cardioprotection is slightly greater with RIC on two legs compared with RIC on one leg [30], another report showed that one and two hindlimb RIC were equally cardioprotective [37]. Given that there are no data regarding the use of multiple limbs in chronic responses to RIC, and we have shown previously that single-limb RIC is effective at modifying autophagy protein responses acutely and chronically $[25,26]$, we chose to use a single limb stimulus for this study.

Echocardiography was performed under anesthesia with isoflurane inhalation by using the Vevo2100 mouse echocardiography system equipped with a $40 \mathrm{MHz}$ highfrequency transducer. Anesthetic depth was kept consistently the same and indicated by similar heart rates, all images being obtained between 400 and 600 beats per
Fig. 1 Study design for RIC intervention. A Early acute protocol. B Late chronic protocol

\section{A Early acute RIC}

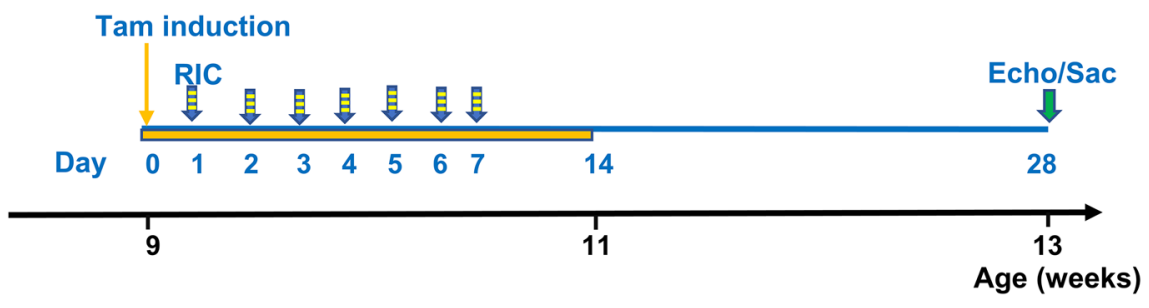

B Late chronic RIC

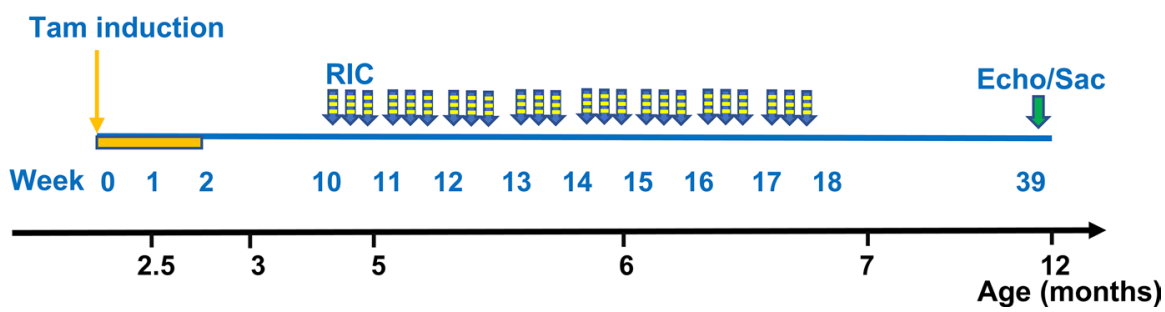


A

B
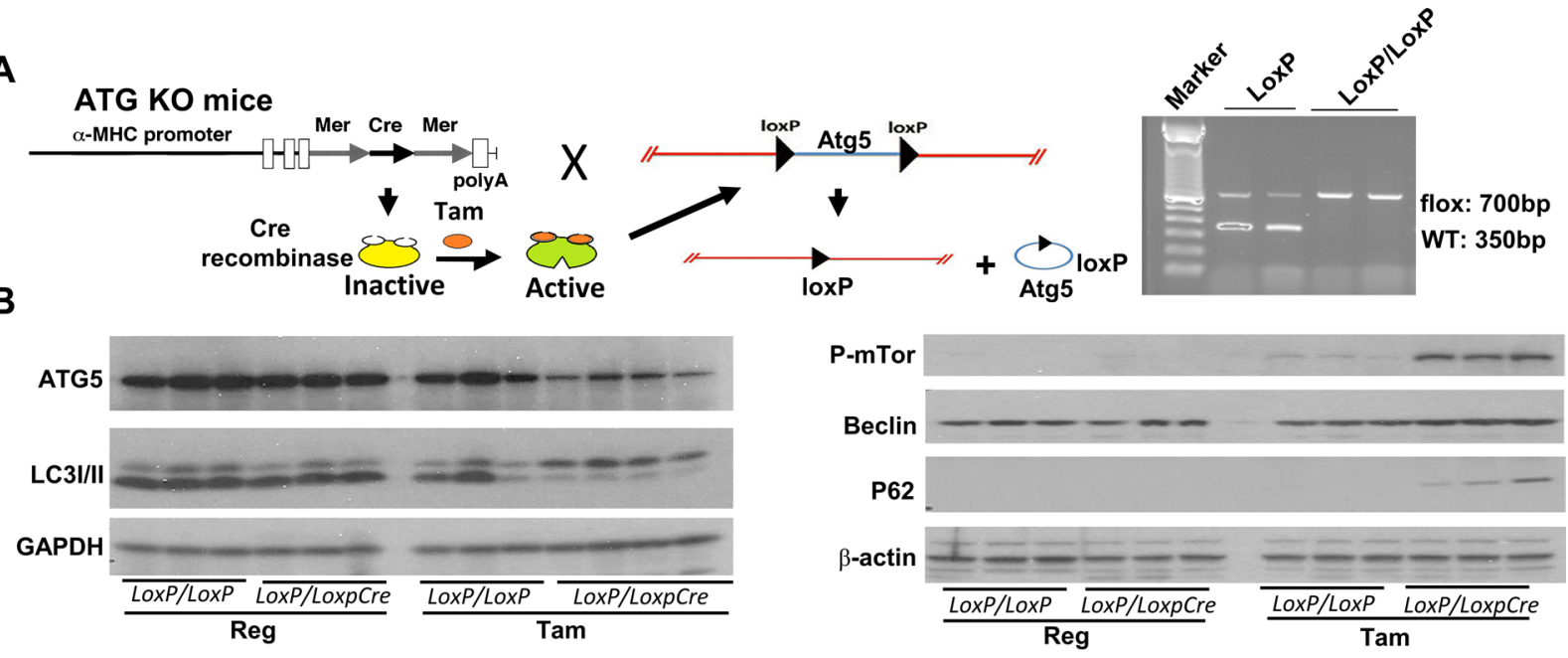

C

LoxP/LoxP

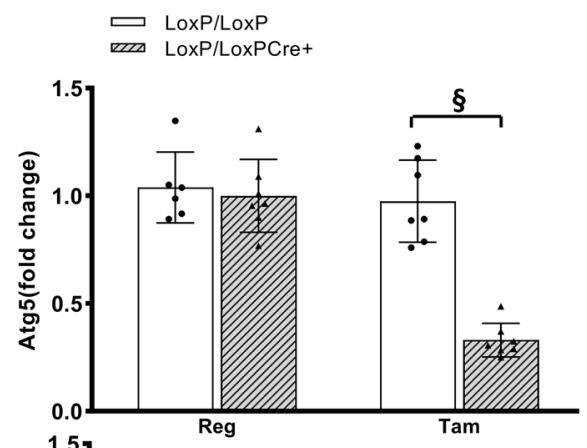

D

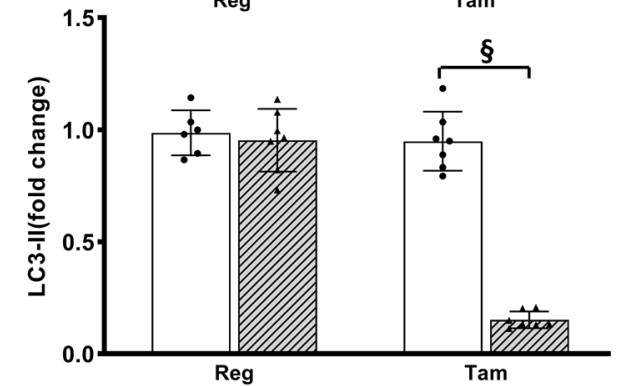

E

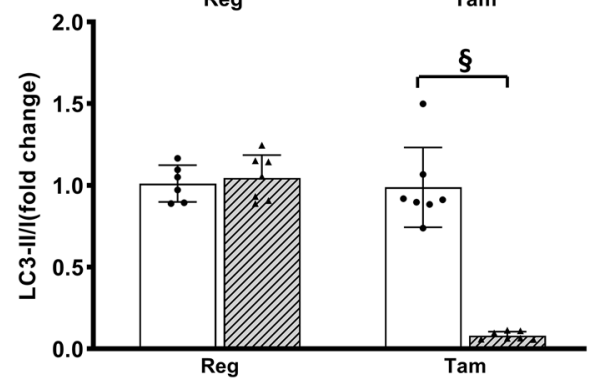

F

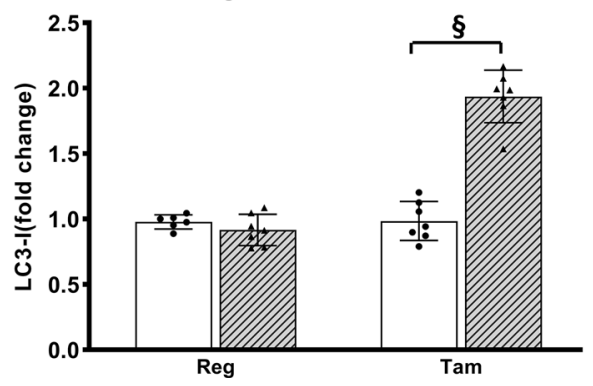

G

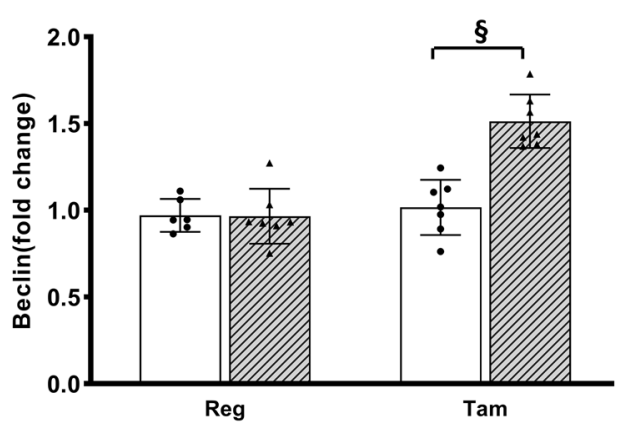

H

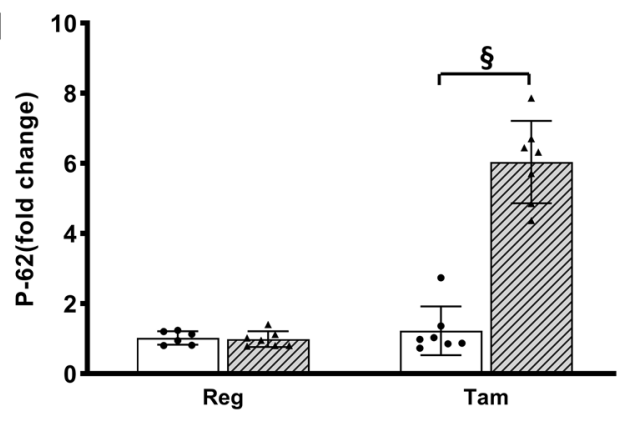

I

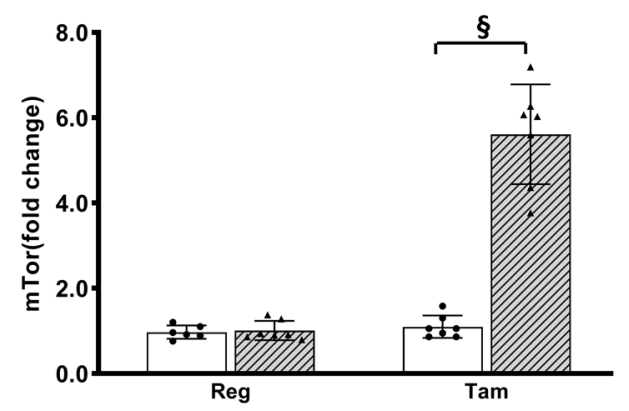


4Fig. 2 Effects of Atg5 knockdown on cardiac autophagy proteins. A Scheme of inducible cardiac-specific Atg5 knockdown and representative image of genotyping. B Representative images of Western blots. Cardiac autophagy proteins were evaluated by Western blot and quantified by Image $\mathbf{J}$ software with tissue extract from myocardium including ATG5 (C), LC3-II (D), LC3-I (F), Beclin (G), P62/ SQSTM1 (H), and phosphor-mTOR (I). The ratio of LC3-II and I was summarized in panel $\mathbf{E} .{ }^{\S} p<0.01$ compared with $\operatorname{Atg} 5^{\text {loxP } / l o x P}$ fed the same diet

minute. Measurements and calculations were made offline by investigators blinded to interventions.

\section{Western blot}

Heart tissue was homogenized in a lysis buffer containing $150 \mathrm{mM} \mathrm{NaCl}, 50 \mathrm{mM}$ Tris. $\mathrm{Cl}$ (pH 7.5), 0.5\% deoxycholate, $0.1 \%$ SDS, $1 \%$ nonidet P-40, PhosSTOP, and Complete Mini. The homogenate was sonicated on ice for 3 strokes of $30 \mathrm{~s}$ at the setting of 125 Watt and $20 \mathrm{kHz}$. Cell extract was collected after centrifugation at $4{ }^{\circ} \mathrm{C}$. Protein concentration was determined using a Pierce BCA protein assay kit and BSA was used as the standards. Relevant cardiac protein levels were determined by Western blot analysis with $50 \mu \mathrm{g}$ total protein as described previously [38] and GAPDH was used as the loading control. LC3 II was also corrected by LC3 I as indicator of autophagy [39].

\section{Histology}

OCT compound preserved myocardial tissue was frozen cut into $6 \mu \mathrm{m}$ slice and mounted onto glass slide for histological staining. After air drying and formalin fixation for $20 \mathrm{~min}$, the slides were incubated with hematoxylin for 10 min and stained with eosin for 3 min after water wash in between stains. The slides were sealed with coverslips after dehydration and xylene clearing.

\section{Sirius red stain}

Frozen sections were air dried for $30 \mathrm{~min}$ at room temperature (RT), then fixed in Bonin's solution for $60 \mathrm{~min}$ at $60{ }^{\circ} \mathrm{C}$ and $10 \%$ formalin for $2 \mathrm{~min}$ at RT, and stained with Pico-Sirius for $60 \mathrm{~min}$ at RT. The slides were washed with acid water and excessive water was removed by vigorous shaking. The slides were sealed with coverslips a resinous medium after dehydration with alcohol and cleared with xylene. Five representative images per slide were obtained under a $20 \times$ objective and collagen area (red stain) was analyzed with Image $\mathbf{J}$ software as previously described in detail [38].

\section{Cardiomyocyte cross-sectional area}

After air drying and fixation in ice-cold acetone, the slides were incubated with $3.3 \mathrm{U} / \mathrm{ml}$ neuraminidase type $\mathrm{v}$ for $60 \mathrm{~min}$ at RT, and thereafter incubated with fluoresceinlabeled Peanut agglutinin and Rhodamine-labeled Griffonia simplicifolia lectin I for $2 \mathrm{~h}$ at RT. The slides were covered with coverslip in presence of anti-fade fluorescent mounting medium and sealed with nail polish. Four representative images were analyzed under a $40 \times$ objective for every slide. Myocyte cross section area (MCSA) was measured with Image $\mathbf{J}$ and averaged the 4 images from each slide.

\section{Statistical analysis}

Data are expressed as the means \pm standard error (SE) unless otherwise noted. For survival experiments, the frequency of death between groups was compared using Fisher Exact Chi-square test. Survival times between groups were compared using Kaplan-Meier analyses with log-rank test. A two-sided $P$ value $<0.05$ was considered significant. All analyses were conducted using SAS version 9.4 (SAS Institute, Cary, North Carolina). For the rest experiments, differences between two groups were analyzed by a two-tailed t-test, while multiple groups were compared using one-way analysis of variance (ANOVA) and Bonferroni-Holm correction. A $p$-value $<0.05$ was regarded as a significant. Analysis was carried out with Excel Office 365.

\section{Results}

\section{Knocking down Atg5 downregulates autophagy with complementary increase in levels of some upstream autophagy proteins in the heart}

Previous studies showed that high level expression of $\mathrm{Cre}$ recombinase in the heart or cardiac-specific knockout Atg5 cause cardiomyopathy $[20,35]$. To maintain a relatively lowlevel expression of CRE recombinase in the heart, heretozygous $\alpha$-MHC MerCreMer transgenic mice were crossed with floxed Atg 5 mice (Fig. 2A). The cardiac-specific expressed $\mathrm{Cre}$, fused with the ligand-binding domain of the murine estrogen receptor, is activated by binding of tamoxifen [40]. Genotyped animals homozygous for LoxP/LoxP and positive $\mathrm{Cre}\left(\mathrm{Atg} 5^{\operatorname{loxP} / l o x P} \mathrm{Cre}\right)$ were used for the experiments. Atg 5 was knocked down by about $70 \%$ in Atg $5^{\text {loxP } / l o x P} C r e$ mice after 14 days tamoxifen treatment, compared with Atg $5^{\operatorname{lox} P / l o x P}$ mice (Fig. 2B, C). ATG12-ATG5 conjugate has been shown to induce E3 ligase activity which facilitates LC3 lipidation and phagophore formation [4], we tested LC3-II and found that it was reduced in Atg5 knockdown hearts compared with control littermates (Fig. 2D). 
The reduced ATG5 was associated with suppressed autophagy as indicated by decreased LC3 II and LC3-II/ LC3-I ratio (Fig. 2E) and markedly increased phosphorylation (at s2481) of mTOR, the master negative regulator of autophagy (Fig. 2I). Other associated autophagy proteins were increased due to the decreased autophagy progression including LC3-I, Beclin and P62/SQSTM1 (Fig. 2F-H).

\section{Knocking down Atg5 impairs cardiac function and shortens life expectancy}

Atg $5^{\text {loxP/loxP }}$ Cre mice developed normally before tamoxifen induction up to 10 weeks old. Cardiac-specific knockdown of Atg5 in adult Atg $5^{\text {loxPlloxP }}$ Cre mouse heart via tamoxifen induction led to time-dependent cardiac functional decline as evaluated by echocardiography. Ejection fraction and fractional shortening gradually decreased from the normal range at baseline to $24 \%$ and $14 \%$ at 17 months, respectively (Fig. 3A and B). Left ventricular internal diameter at end diastole (LVIDD) and end systole (LVIDS) were very significantly increased at 17 months compared with Atg $5^{\text {loxP/loxP }}$ Cre mice fed with regular chow or Cre negative littermates fed tamoxifen diet (Fig. 3C and D). Heart weight was also very significantly increased in $\mathrm{Atg} 5^{\text {loxP/loxP }} \mathrm{Cre}$ mice with tamoxifen diet compared with $C r e$ negative littermates (Fig. 3E). The cardiac function of Atg $5^{\text {loxP/loxP }}$ Cre mice was not different from $\mathrm{Cre}$ negative littermates without tamoxifen induction. The survival rate of Atg5 knockdown mice was markedly decreased with approximately $40 \%$ mice surviving to 17 months compared with $100 \%$ of Cre negative littermates and $92 \%$ of Atg $5^{\text {loxP/loxP }}$ Cre mice without tamoxifen induction (Fig. 3F). Autopsy showed that premature death was caused by congestive heart failure.

\section{Early acute RIC intervention rescues ATG5 protein and autophagy signaling defects in cardiac-specific Atg5 knockdown mice}

Our previous study showed that the cardioprotective effects of RIC in post-MI remodeling cardiomyopathy was associated with enhanced autophagy signaling [26]. We tested if RIC rescues cardiac-specific Atg 5 knockdown suppressed autophagy signaling and found that RIC modified multiple autophagy signaling proteins (Fig. 4A). Daily RIC for 7 days during tamoxifen induction reduced $\mathrm{mTOR}$ phosphorylation compared with sham RIC procedure (Fig. 4B), and also significantly increased ATG5 levels compared with sham (Fig. 4C). However, the ATG5 level was only partially rescued to just over 50\% of control levels (Supplementary sFig.1). Other tested autophagy proteins, including Beclin and P62/SQSTM1, were also enhanced by RIC (Fig. 4D and E). LC3II/I ratio was also significantly enhanced by RIC compared with sham treated animals (Fig. 4F). The reduced mTOR phosphorylation and enhanced autophagy protein levels are compatible with RIC-enhanced autophagy in Atg5 KD hearts.

\section{Early acute RIC enhances cardiac function in cardiac-specific Atg5 knockdown mice}

As showed in Fig. 5A, RIC improved cardiac contractility in the Atg $5 \mathrm{KD}$-induced cardiomyopathy animals. RIC significantly improved left ventricular ejection fraction and fraction shortening as evaluated by echocardiography (Fig. 5B and C). Besides functional improvement, RIC also prevented the heart weight increase seen in the sham RIC group (Fig. 5D).

\section{Early acute RIC improved cardiac function is associated with improved myocardial remodeling in cardiac-specific Atg5 knockdown mice}

We investigated if the improved cardiac function in RIC treated Atg5 knockdown mice is associated with myocardial remodeling. As showed in Fig. 6A, H\&E staining showed that RIC reduced intermyofibrillar spacing suggesting reduced fibrosis. The extracellular collagen deposition determined by Sirius Red staining was significantly reduced in RIC treated Atg 5 knockdown mice compared with sham operations (Fig. 6A and B). Myocyte hypertrophy indicated by MCSA was also reduced by RIC compared with Sham (Fig. 6A and C).

\section{Late chronic RIC rescues ATG5 protein and other autophagy signaling defects in cardiac-specific Atg5 knockdown mice}

Similar to early acute RIC, late chronic RIC modified autophagy proteins. As showed in Fig. 7, RIC decreased mTOR phosphorylation and increased ATG5 compared with sham RIC (Fig. 7A-C). The ATG5 level in the RIC group was $41 \%$ of normal control level (Supplementary Fig. 2). RIC also increased Beclin (Fig. 7D) but not p62 levels (Fig. 7E). However, the LC3 II/I ratio (Fig. 7F) was also induced, indicating autophagy was enhanced by RIC.

\section{Late chronic RIC effectively prevented heart weight increase and was associated with non-significant improvement in functional characteristics}

Though late chronic RIC tended to improve cardiac function (Fig. 8A-C) as evaluated by echocardiographic $\mathrm{EF}(p<0.13)$ and FS $(p<0.15)$, this failed to reach statistical significance. However, RIC delivered per protocol B significantly 


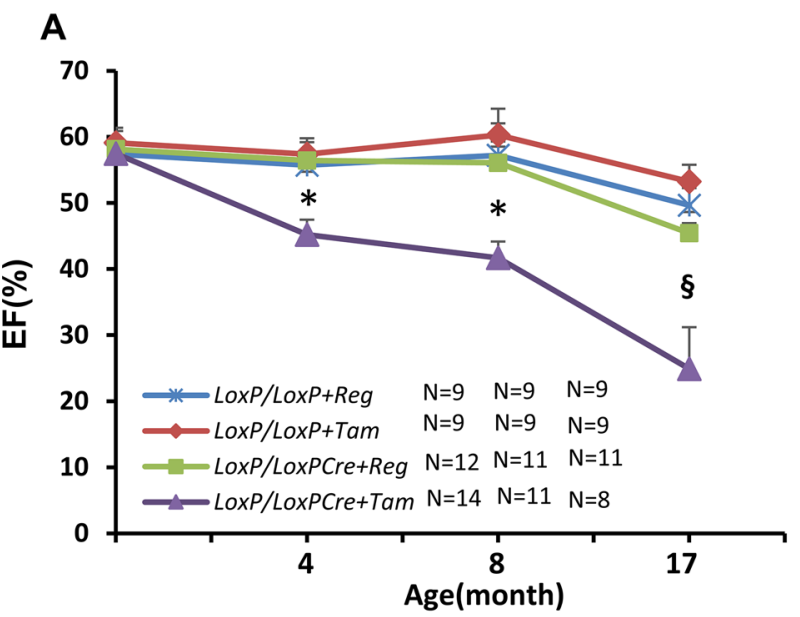

B

C

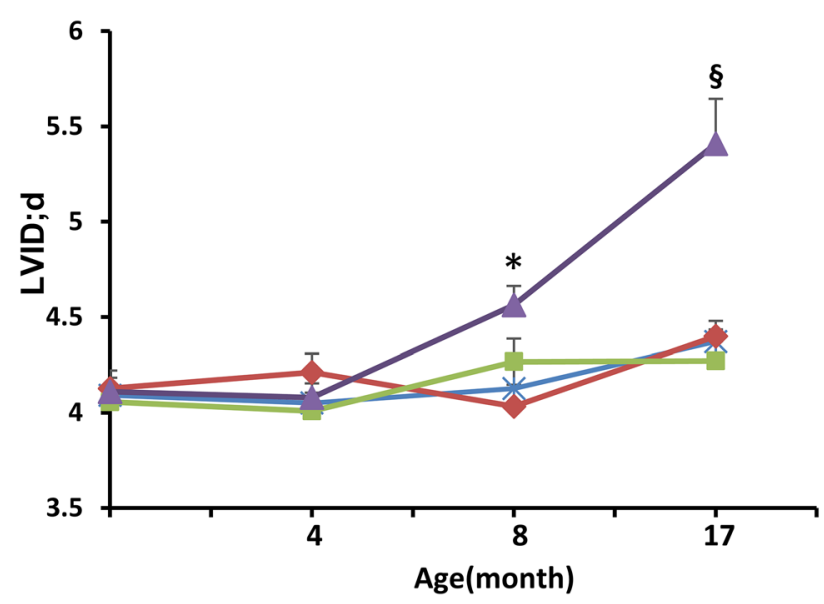

E LoxP/LoxP

LoxP/LoxPCre+

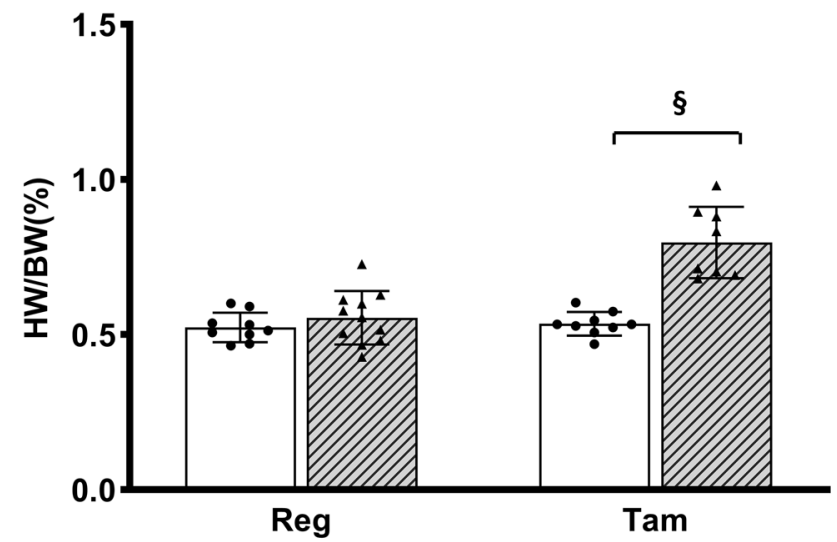

Fig. 3 Atg5 knockdown impaired cardiac function and survival. Cardiac-specific knock down of Atg5 induced time-dependent decreased in left ventricular ejection fraction (EF) (A) and FS (B), increased LVIDD (C) and LVIDS (D), increased heart weight/body weight ratio

(E), and decreased survival (F). Only animals alive at the end of the protocol were analyzed in panel E. $* p<0.05$ and ${ }^{\S} p<0.01$ compared with Atg5 $5^{\text {loxP } / l o x P}$ fed the same diet

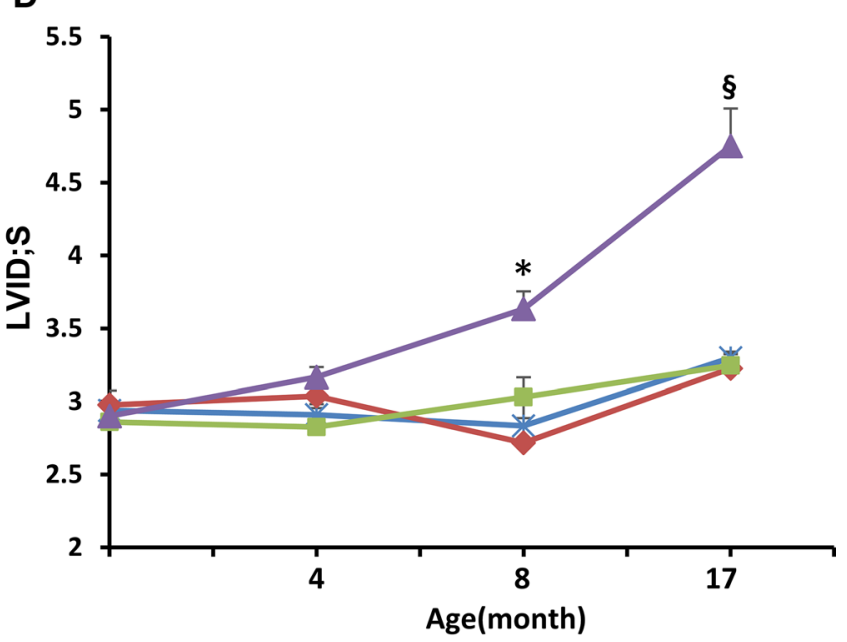

$\mathbf{F}$

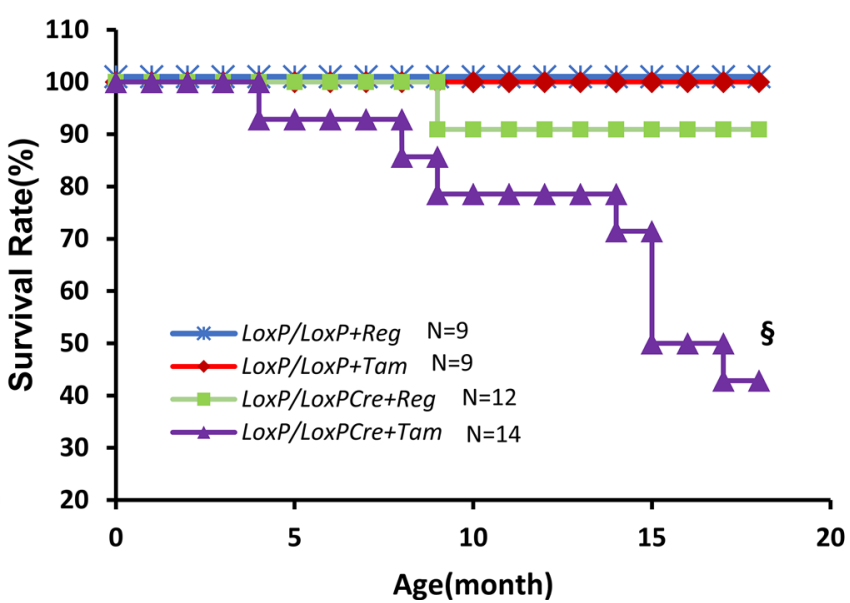


Fig. 4 Early acute RIC modified autophagy-related proteins in Atg 5 knockdown heart. A Representative Western blot images. RIC activated autophagy proteins in Atg5 knockdown heart including phospho-mTOR (B), ATG5 (C), Beclin (D), and P62/SQSTM1 (E) compared with Sham operation. The ratio of LC3-II and I (F) was also increased compared with Sham RIC. ${ }^{\#} p<0.01$ compared with Sham
A
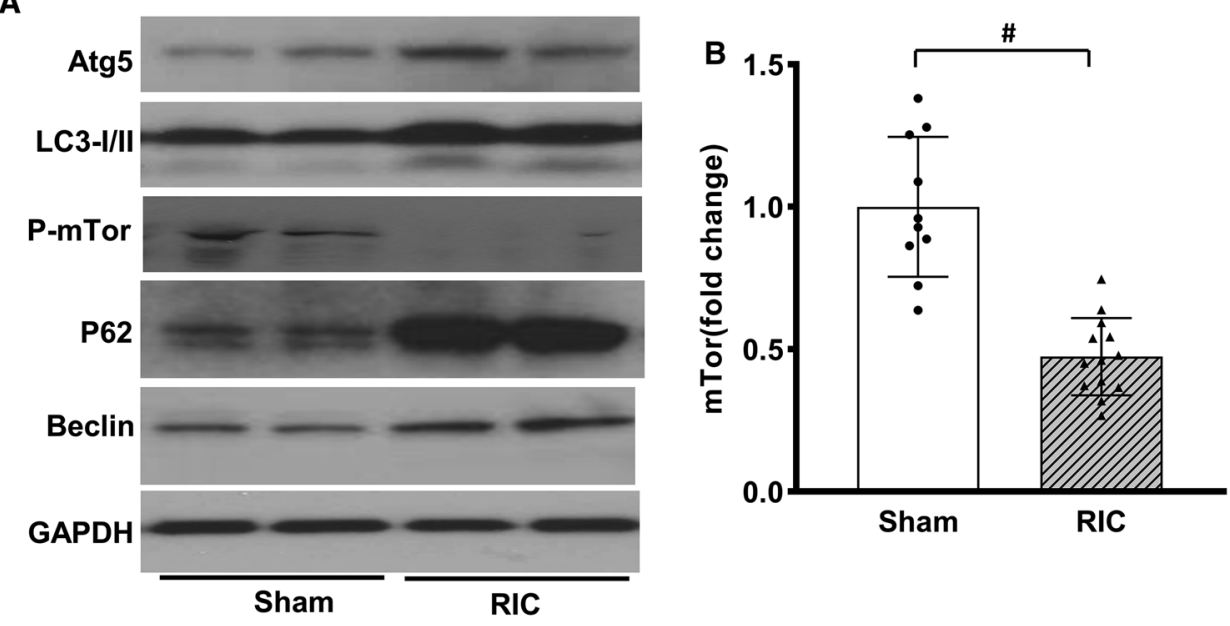
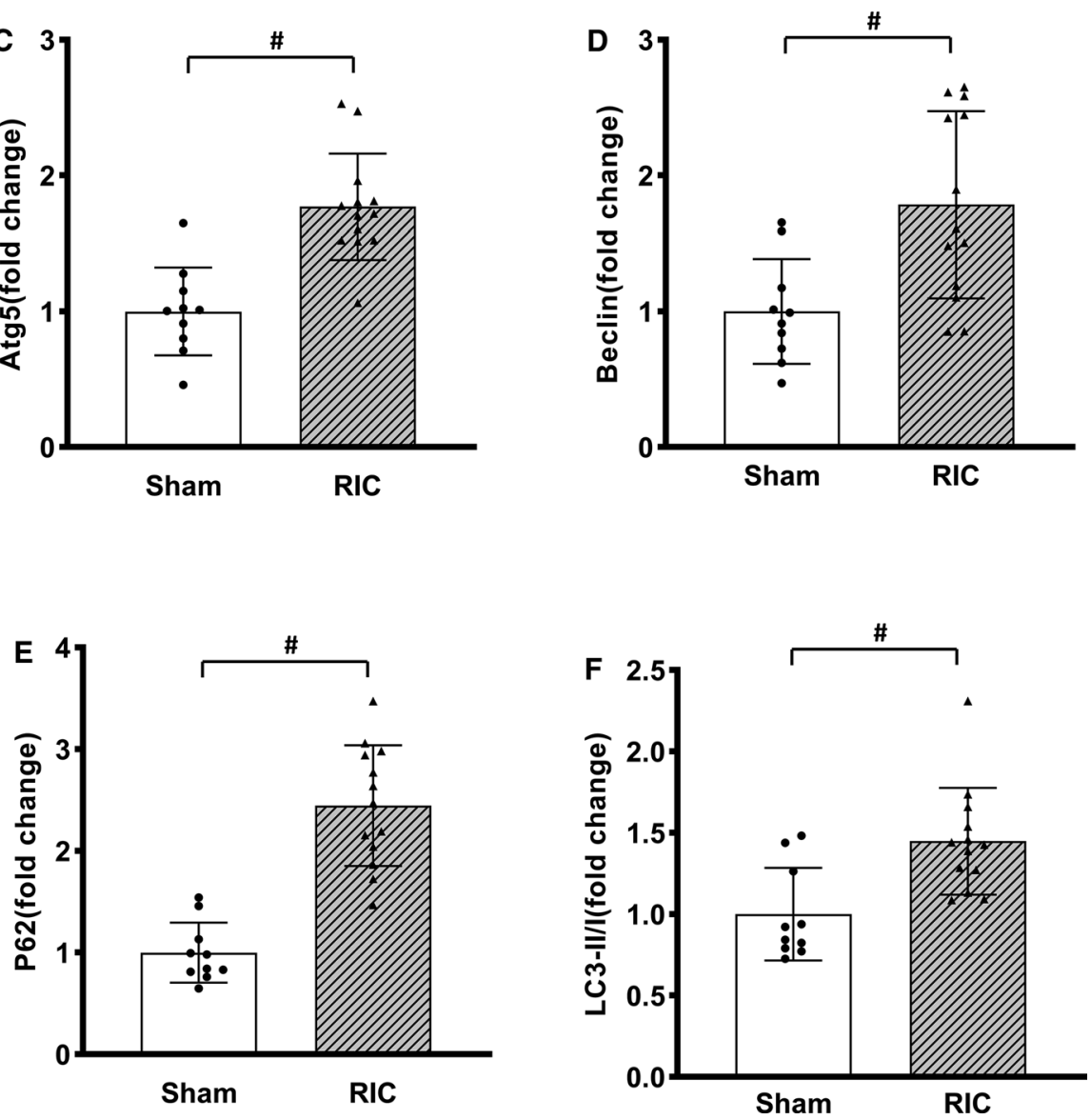

prevented heart weight increases compared with sham RIC (Fig. 8D). Late chronic RIC had non-significant survival benefit $(p<0.31$, Fig. 8E).

\section{Discussion}

Autophagy is a critically important function for cardiac myocytes to maintain the quality of intracellular proteins and organelles. Atg 5 is a key protein involved in formation of the autophagosome, and gene knockdown in our study was associated with markedly increased phosphor-mTOR (a negative 
Fig. 5 Effects of early acute RIC on cardiac function in Atg5 knockdown cardiomyopathic mice. A Represent echocardiography images. Cardiac function was evaluated by echocardiography and quantified by $\mathrm{EF}(\mathbf{B})$ and FS $(\mathbf{C})$. D Heart eight and body weight ratio. $* p<0.05$ compared with Sham
A

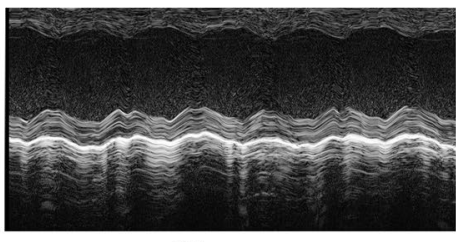

Sham

B

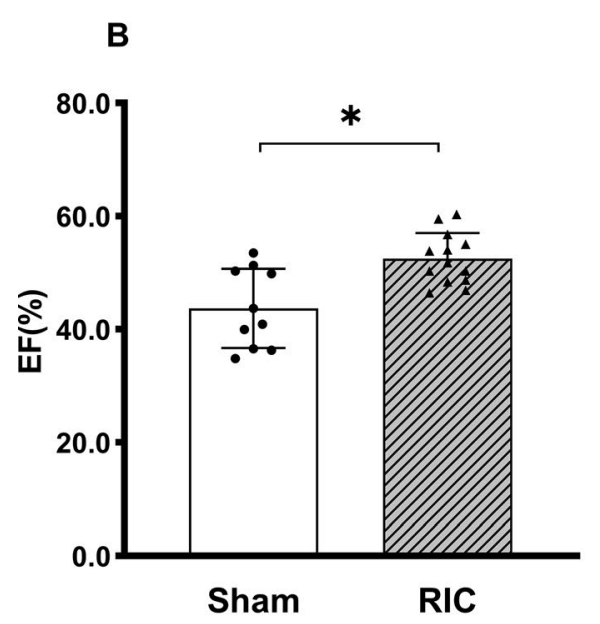

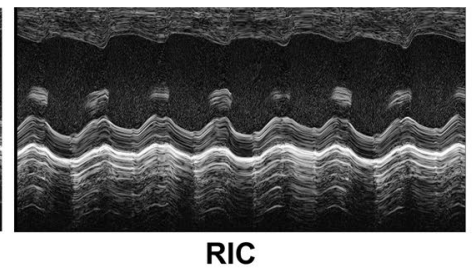

RIC
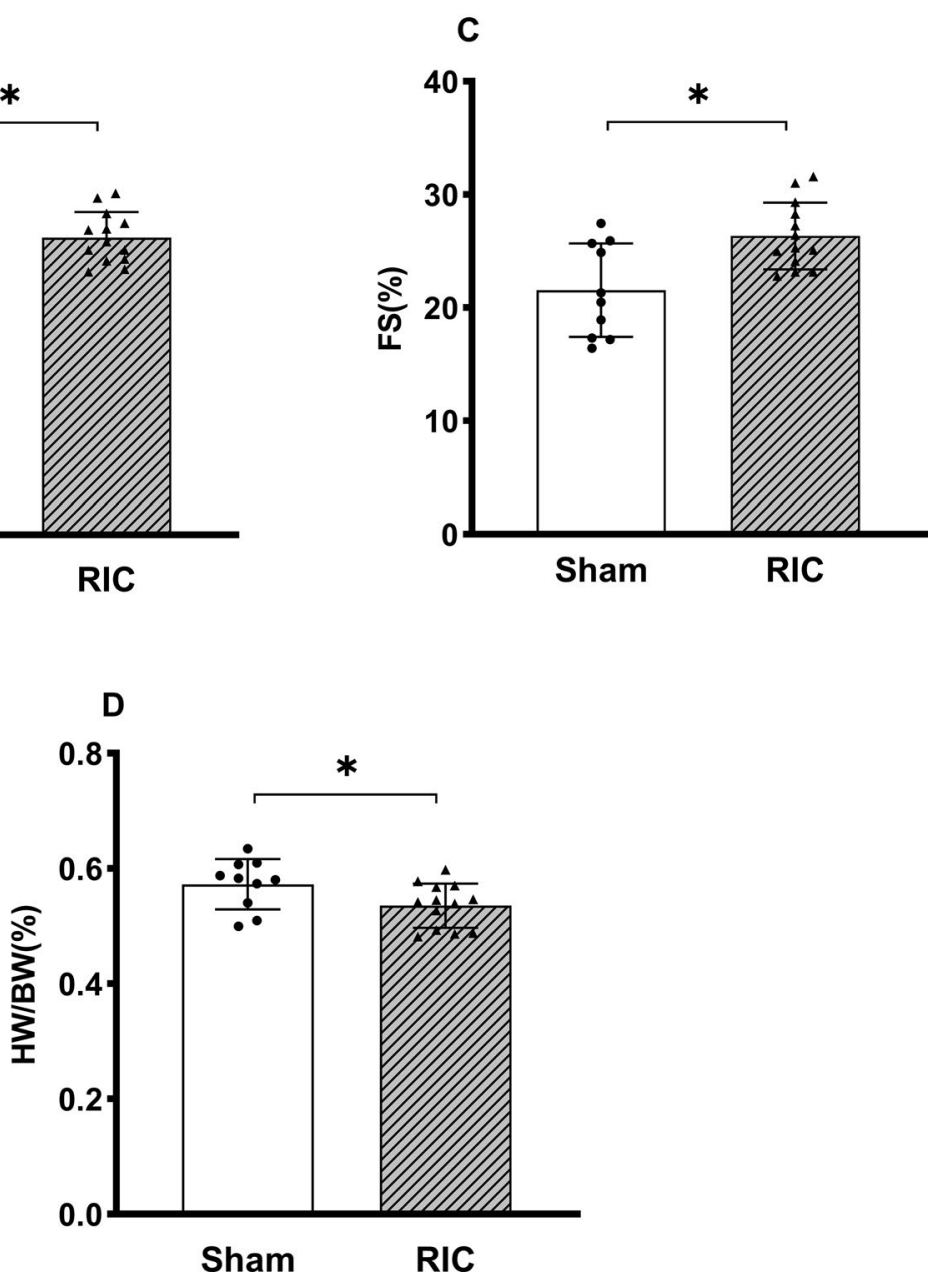

regulator of autophagy) and reduced LC3-II (a microtubuleassociated protein, which is recruited to autophagosomal membranes). There was also an increase of pro-autophagy associated proteins -P62/SQSTM1 (an autophagy receptor for ubiquitinated cargos via interaction with ubiquitin and LC3), LC3-I, and Beclin, presumably because of disruption of the autophagasome completion, downstream of their induction, but the net effect was a reduction of net autophagy as reflected by the decreased LC3-II/LC3-I ratio. We were initially surprised to find such a pronounced increase in mTOR with Atg 5 knockdown, but overexpression of p62 has been shown to activate mTOR in several models [41-43]. mTOR is a ubiquitously expressed core serine/threonine protein kinase component of mTOR complex 1 and mTOR

complex 2, which regulates multiple biological processes including protein synthesis, autophagy, gene transcription; and cell growth, proliferation, motility, and survival. Activation of mTOR increases protein synthesis and cell growth but suppresses autophagy. In contrast, inhibition of mTOR enhances autophagy but inhibits cell growth. mTOR can be activated by binding to partner proteins and phosphorylation at S1261, S2159, T2164, S2481, T2446, and S2448. Our data showed that Atg5 KD increased p62 and phosphor-mTOR (Fig. 2) and this is consistent with a previous report showing that liver-specific Atg 5 knock out mice had increased hepatic p62 and activation of mTOR [44].

Consequently, Atg5 knockdown induced age-dependent reduction in cardiac function and shortened life span 
A

HE

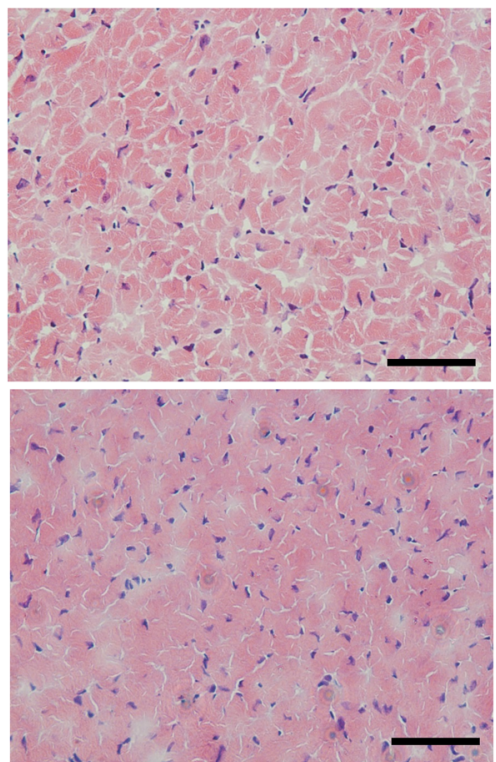

Black scale bar: $20 \mu \mathrm{m}$
Sirius Red
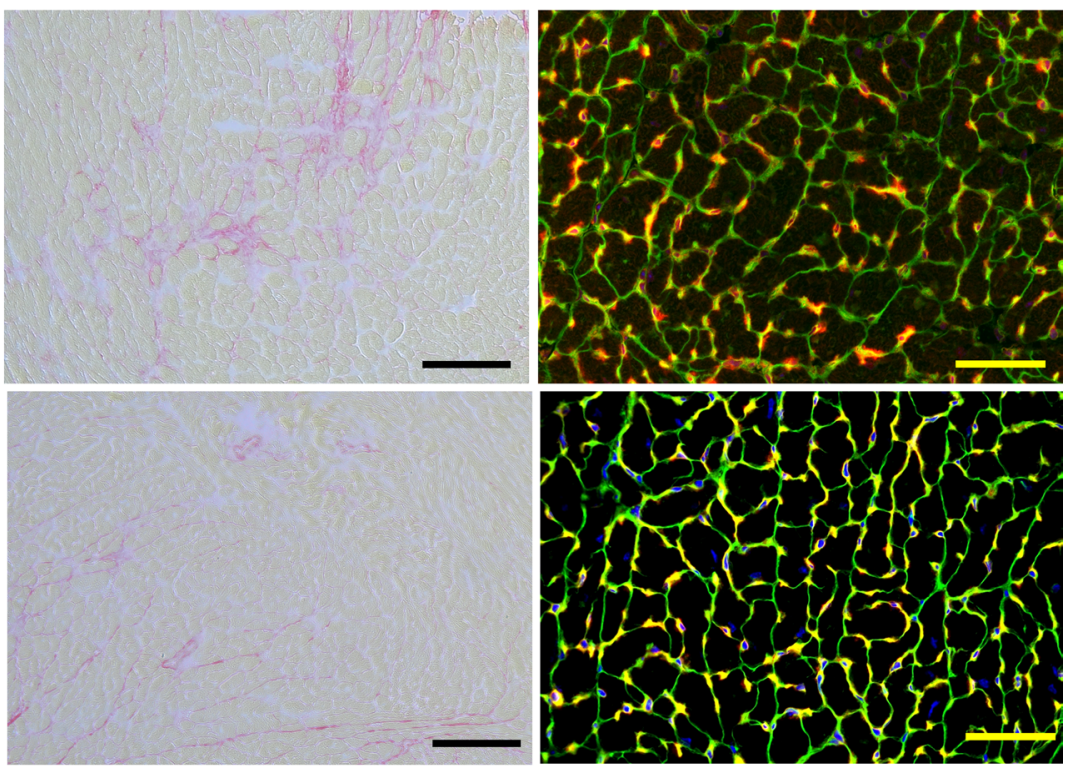

Yellow scale bar: $25 \mu \mathrm{m}$
B

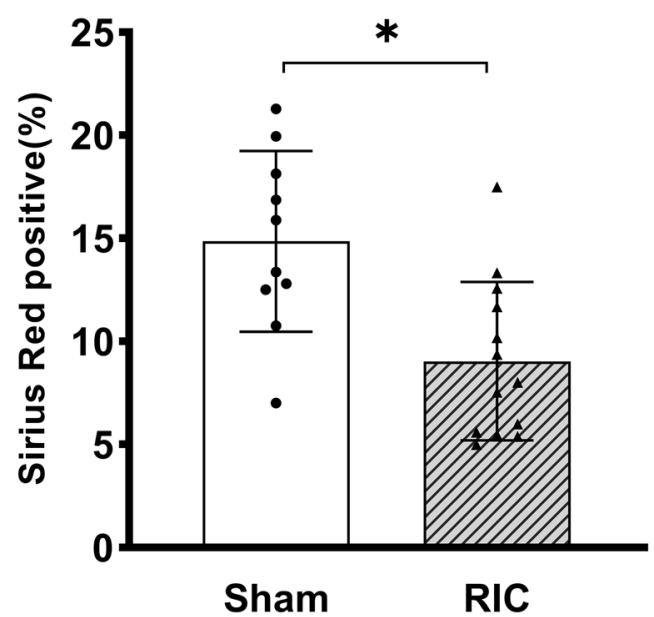

C

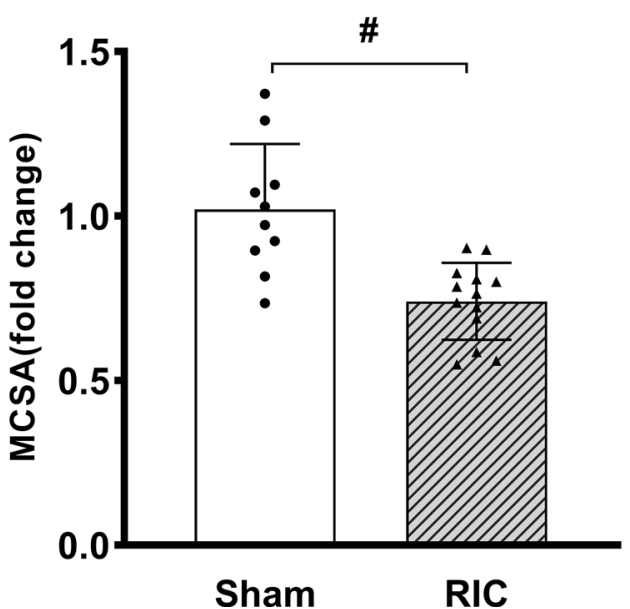

Fig. 6 Effects of early acute RIC on cardiac remodeling in Atg5 knockdown mice. A Representative image for H\&E, Sirius Red, and MCSA stains. Positive Sirius Red stains and MCSA were quantified in panel $\mathbf{B}$ and $\mathbf{C}$ respectively. ${ }^{*} p<0.05$ and ${ }^{\#} p<0.01$ compared with Sham

(Fig. 3). These data are consistent with previous reports [20, 45] showing early onset, fatal, cardiac dysfunction in Atg5 knockout mice. In our study, we were able to study the time course of functional decline over 17 months as the CRE level was limited by using heterozygous Cre animals. This is important as previous studies have shown that cardiacspecific overexpressed CRE itself can cause cardiomyopathy $[35,46]$. The phenotype and myocardial biology in our model was quite different to the previously reported 'cre-induced' cardiomyopathy, which was uniformly fatal by 11 months of age in one long-term study. Reinforcing the difference, in our Atg $5^{\operatorname{loxP} / \operatorname{lox} P} \mathrm{Cre}$ animals without tamoxifen induction survival was $92 \%$ at 17 months, while ATG5 knockdown reduced survival to $40 \%$ during the same period. The reduced survival was associated with clear differences in autophagy signaling in the Atg 5 knockdown mice, and markedly reduced left ventricular function, both of which were rescued by RIC. 
Fig. 7 Late chronic RIC modified autophagy-related proteins in Atg 5 knockdown heart. A Representative Western blot images. Late chronic RIC induced autophagy proteins in Atg5 knockdown heart including phospho-mTOR (B), ATG5 (C), and Beclin (D) compared with Sham operation. E P62/ SQSTM1. The ratio of LC3-II and I (F) was also increased compared with Sham RIC. ${ }^{*} p<0.05$ compared with Sham
A

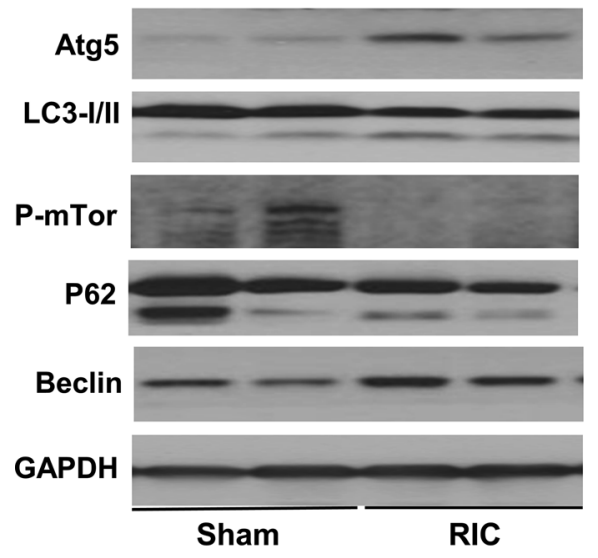

C

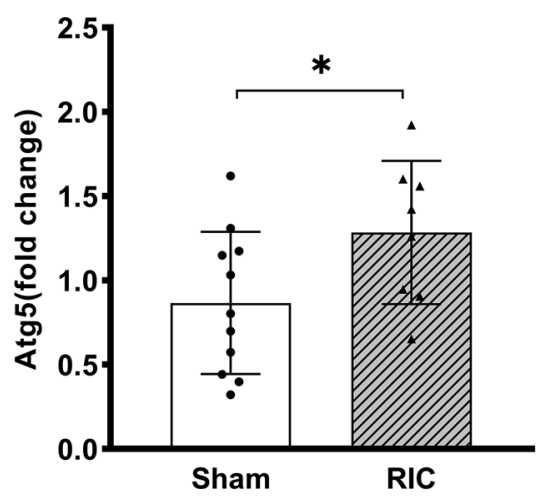

E

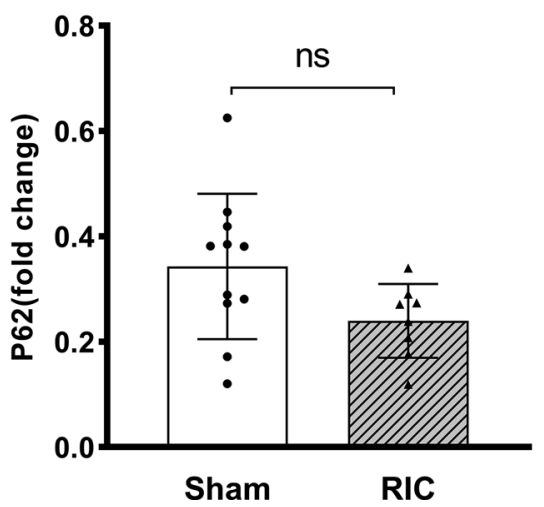

B

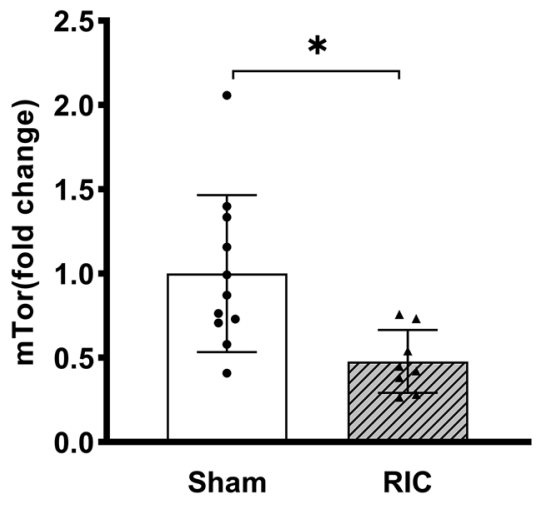

D

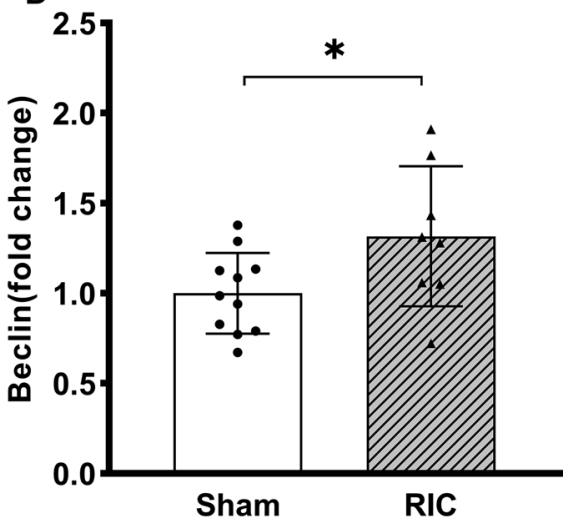

F

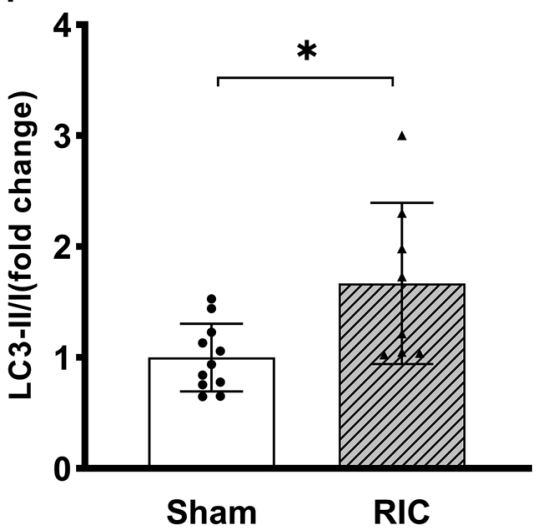

Indeed, our data show that both RIC protocols increased autophagy signaling, including increased expression of ATG5 and Beclin, as well as a reduction in phosphor-mTOR, leading to elevated autophagy as indicated by increased LC3-II/I ratio (Fig. 4 and 7). These findings are consistent with our previous reports showing that RIC increases autophagy signaling in several different models [25, 26, 47-49]. However, in some reports, albeit in different models with different RIC protocols (in large animals subjected to intracoronary doxorubicin infusion [31], an acute human cardiac surgical intraoperative study [32] and doxorubicin toxicity in a mouse model [33]) have shown that RIC has no effect or even decreases autophagy signaling, emphasizing the need for disease-specific models in regard to the effects of RIC. Nonetheless, it is well known that impaired autophagy is associated with a variety of human diseases [3] including cardiovascular diseases. Some of these can be modeled in animals, whereby activation of autophagy 
Fig. 8 Effects of late chronic RIC on cardiac function in Atg5 knockdown cardiomyopathic mice. A Represent echocardiography images. Cardiac function was evaluated by echocardiography and quantified by $\mathrm{EF}(\mathbf{B})$ and FS (C). Heart weight and body weight ratio and survival data were summarized in panel $\mathrm{D}$ and $\mathrm{E} . * p<0.01$ compared with Sham
A
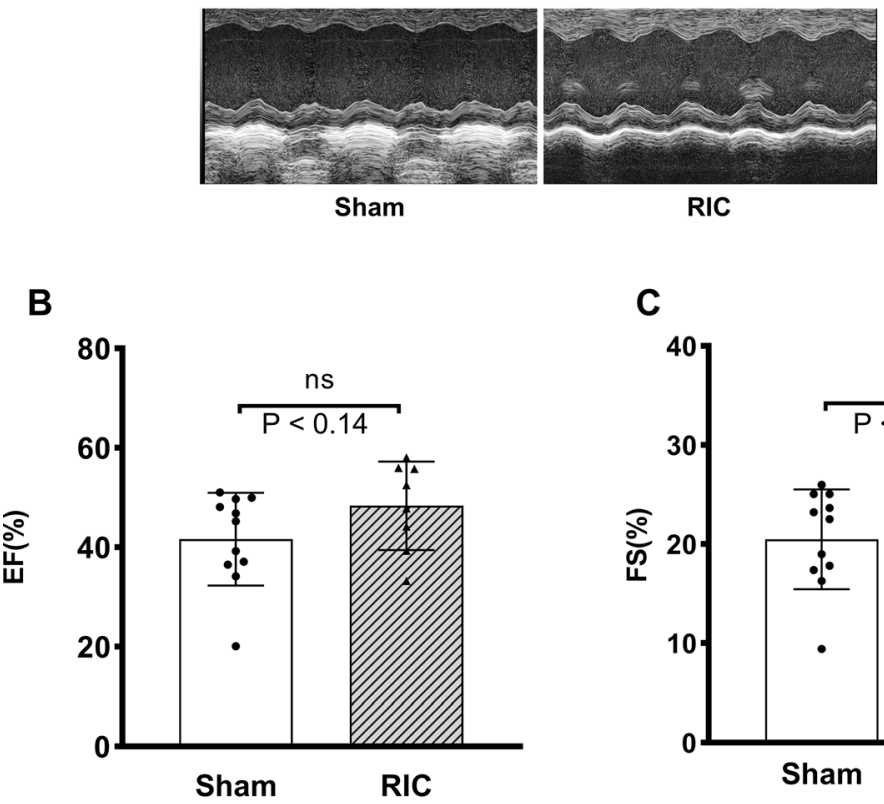

C
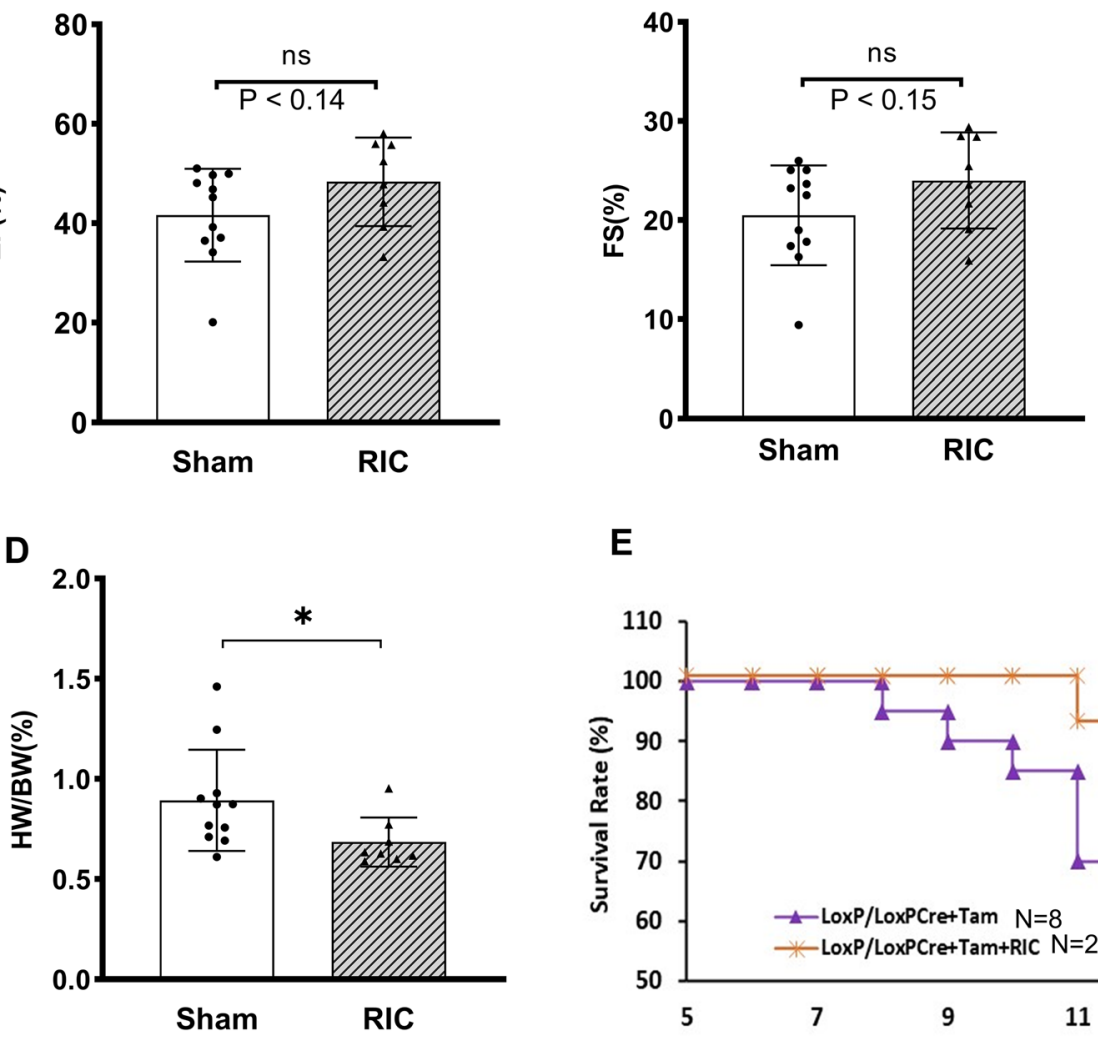

E

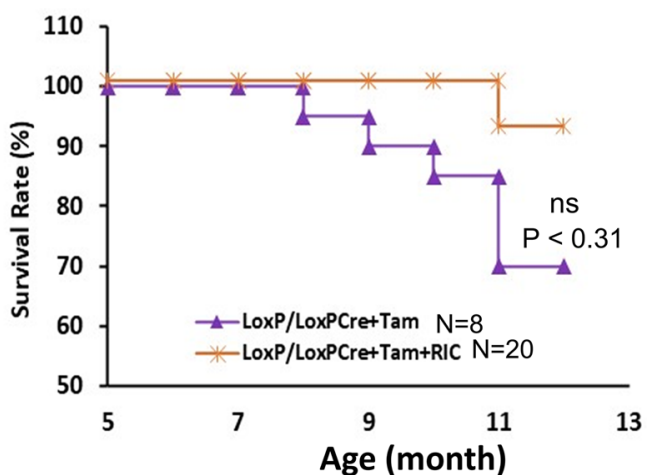

improves cardiac remodeling after myocardial infarction [50], and inhibition of autophagy induces cardiac hypertrophy [20], for example. Our data showed that RIC reduced Atg5 knockdown-induced left ventricular remodeling as reflected by improved systolic function, increased cardiac myocyte cross sectional area, and reduced interstitial collagen deposition (Fig. 6). This effect is similar to the effects of RIC in other forms of cardiac remodeling and failure, including myocardial infarction [51] and chronic doxorubicininduced cardiomyopathy [25]. We report, here for the first time, that RIC increases autophagy signaling in a genetic model of autophagy downregulation, suggesting that the beneficial effects of RIC may be relevant to human diseases associated with modified autophagy, whether induced by genetic polymorphisms or other manifestations of disease.

The cardiomyopathy phenotype in our study aligns well with that of many forms of human cardiomyopathy, in that it is relatively slowly progressive, with late mortality associated with slow functional decline that is age-related [21]. There was therefore a potential 'therapeutic window' where RIC administration was able to show benefit on autophagy signaling and functional decline in our animals, that may also exist in patients with some forms of inherited and toxic-cardiomyopathies (e.g. anthracyline toxicity-related cardiomyopathy). In our study $40 \%$ of the Atg5 KD mice survived to 17-month-old which equivalent to human age of approximately 60 years old [52], making it a unique model applicable to study the effect of other long-term interventions to treat heart failure. That said, we must be somewhat circumspect in regard to the clinical translatability in regards to the potential clinical benefit of RIC in our current study, as translation of the benefits of RIC shown in experimental and early phase clinical studies has frequently failed in phase III randomized clinical trials [27, 28]. The reasons for this have been widely debated. Multiple factors for lack of clinical translation 
have been suggested, including older patient age [53], gender [30, 53], the effect of comorbidities such as diabetes [54], and the concomitant use of drugs that may block the RIC effect or themselves induce a 'conditioned' state [55]. Given that patients with inherited and other non-ischemic cardiomyopathies tend to be younger, with fewer agerelated co-morbidities, there is perhaps some hope that if the beneficial effects of RIC are confirmed and optimized in future animal models, that translatability might be higher. The need for such optimization studies is crucial, particularly when RIC is being administered repeatedly and chronically given concerns regarding the potential adverse effects of hyperconditioning [56]. Furthermore, the current study, using daily administration of RIC to a single limb, while showing both short-term and long-term benefits, had somewhat different outcomes. It appears that RIC works better, at least in terms of functional outcomes, when used early, but further studies are clearly required.

\section{Study limitations}

Previous studies have shown that RIC may be more effective in males than females $[53,57]$. Only male mice were used in this study and so similar experiments should be performed with females in future studies. While our data showed that RIC improved Atg5 knockdown-induced myocardial remodeling was associated with marked differences in autophagy signaling, we are unable to prove a causal relationship, and other potential mechanisms of protection, such as the apoptosis pathway [25], and protein kinases [24], which are involved in RIC-induced cardioprotection, should be examined in future mechanistic studies. The late chronic RIC survival experiment was terminated prematurely due to the COVID-19 shut down and this limited our statistical power to show differences in functional outcomes, all of which trended towards improvement, but were not statistically significantly different. Nonetheless, the heart weight increase seen in sham-treated animals was significantly attenuated by chronic, late, RIC. Finally, as discussed above, the translatability of this technique, while technically straightforward, remains to be determined at a functional level. Future studies of the role of repeated RIC in human cardiomyopathy should concentrate on those phenotypes where early intervention might be applied to patients with a known progressive disease, rather than reversal of established end-stage disease, when and if the experimental data is mature enough to justify clinical trials. We would suggest that further experimental studies examining and optimizing dose response etc. are required prior to such studies, but the current study provides a rationale, and some optimism, for such studies to guide clinical translation.

\section{Conclusions}

Cardiac-specific Atg5 knockdown leads to altered autophagy signaling and is associated with age-related cardiomyopathy and premature death. RIC is an effective approach to restore autophagy signaling, rescues Atg 5 knockdown-induced cardiomyopathy, and prolongs life. The benefits of RIC may potentially extend to other cardiovascular disorders associated with altered autophagy signaling.

Supplementary Information The online version contains supplementary material available at https://doi.org/10.1007/s00395-021-00888-2.

Acknowledgements We would like to acknowledge Victoria Moore and Chrissy Schulte from the Cardiovascular Imaging Core Research Laboratory of Cincinnati Children's Hospital for their support in echocardiography.

Funding Financial support was from the Cincinnati Children's Research Fund.

\section{Declarations}

Conflict of interest None of the authors have conflict of interests to report.

\section{References}

1. Dowling JJ, Moore SA, Kalimo H, Minassian BA (2015) $\mathrm{X}$-linked myopathy with excessive autophagy: a failure of selfeating. Acta Neuropathol 129:383-390. https://doi.org/10.1007/ s00401-015-1393-4

2. Dasari SK, Bialik S, Levin-Zaidman S, Levin-Salomon V, Merrill AH Jr, Futerman AH, Kimchi A (2017) Signalome-wide RNAi screen identifies GBA1 as a positive mediator of autophagic cell death. Cell Death Differ 24:1288-1302. https://doi.org/10.1038/ cdd. 2017.80

3. Choi AM, Ryter SW, Levine B (2013) Autophagy in human health and disease. N Engl J Med 368:1845-1846. https://doi.org/10. 1056/NEJMc1303158

4. Otomo C, Metlagel Z, Takaesu G, Otomo T (2013) Structure of the human ATG12 ATG5 conjugate required for LC3 lipidation in autophagy. Nat Struct Mol Biol 20:59-66. https://doi.org/10. 1038/nsmb.2431

5. Pankiv S, Clausen TH, Lamark T, Brech A, Bruun JA, Outzen H, Overvatn A, Bjorkoy G, Johansen T (2007) p62/SQSTM1 binds directly to Atg8/LC3 to facilitate degradation of ubiquitinated protein aggregates by autophagy. J Biol Chem 282:24131-24145. https://doi.org/10.1074/jbc.M702824200

6. Cho SJ, Lim HJ, Jo C, Park MH, Han C, Koh YH (2019) Plasma ATG5 is increased in Alzheimer's disease. Sci Rep 9:4741. https:// doi.org/10.1038/s41598-019-41347-2

7. Hu ZY, Chen B, Zhang JP, Ma YY (2017) Up-regulation of autophagy-related gene 5 (ATG5) protects dopaminergic neurons in a zebrafish model of Parkinson's disease. J Biol Chem 292:18062-18074. https://doi.org/10.1074/jbc.M116.764795

8. Kim M, Sandford E, Gatica D, Qiu Y, Liu X, Zheng Y, Schulman BA, Xu J, Semple I, Ro SH, Kim B, Mavioglu RN, Tolun A, Jipa A, Takats S, Karpati M, Li JZ, Yapici Z, Juhasz G, Lee JH, 
Klionsky DJ, Burmeister M (2016) Mutation in ATG5 reduces autophagy and leads to ataxia with developmental delay. Elife. https://doi.org/10.7554/eLife.12245

9. Kosacka J, Kern M, Kloting N, Paeschke S, Rudich A, Haim Y, Gericke M, Serke H, Stumvoll M, Bechmann I, Nowicki M, Bluher M (2015) Autophagy in adipose tissue of patients with obesity and type 2 diabetes. Mol Cell Endocrinol 409:21-32. https://doi.org/10.1016/j.mce.2015.03.015

10. Riahi Y, Wikstrom JD, Bachar-Wikstrom E, Polin N, Zucker H, Lee MS, Quan W, Haataja L, Liu M, Arvan P, Cerasi E, Leibowitz G (2016) Autophagy is a major regulator of beta cell insulin homeostasis. Diabetologia 59:1480-1491. https://doi.org/10.1007/ s00125-016-3868-9

11. Zhang Y, He X, Li J, Yang W, Cui Y, Pang S, Wang H, Yan B (2020) Functional genetic variant in ATG5 gene promoter in acute myocardial infarction. Cardiol Res Pract. https://doi.org/10.1155/ 2020/9898301

12. Ciccacci C, Perricone C, Alessandri C, Latini A, Politi C, Delunardo F, Pierdominici M, Conti F, Novelli G, Ortona E, Borgiani P (2018) Evaluation of ATG5 polymorphisms in Italian patients with systemic lupus erythematosus: contribution to disease susceptibility and clinical phenotypes. Lupus 27:1464-1469. https:// doi.org/10.1177/0961203318776108

13. International Consortium for Systemic Lupus Erythematosus G, Harley JB, Alarcon-Riquelme ME, Criswell LA, Jacob CO, Kimberly RP, Moser KL, Tsao BP, Vyse TJ, Langefeld CD, Nath SK, Guthridge JM, Cobb BL, Mirel DB, Marion MC, Williams AH, Divers J, Wang W, Frank SG, Namjou B, Gabriel SB, Lee AT, Gregersen PK, Behrens TW, Taylor KE, Fernando M, Zidovetzki R, Gaffney PM, Edberg JC, Rioux JD, Ojwang JO, James JA, Merrill JT, Gilkeson GS, Seldin MF, Yin H, Baechler EC, Li QZ, Wakeland EK, Bruner GR, Kaufman KM, Kelly JA (2008) Genome-wide association scan in women with systemic lupus erythematosus identifies susceptibility variants in ITGAM, PXK, KIAA1542 and other loci. Nat Genet 40:204-210. https://doi.org/ $10.1038 / n g .81$

14. Zhang YM, Cheng FJ, Zhou XJ, Qi YY, Hou P, Zhao MH, Zhang $\mathrm{H}$ (2015) Detecting genetic associations between ATG5 and lupus nephritis by trans-eQTL. J Immunol Res. https://doi.org/10.1155/ 2015/153132

15. Zhou XJ, Lu XL, Lv JC, Yang HZ, Qin LX, Zhao MH, Su Y, Li ZG, Zhang H (2011) Genetic association of PRDM1-ATG5 intergenic region and autophagy with systemic lupus erythematosus in a Chinese population. Ann Rheum Dis 70:1330-1337. https:// doi.org/10.1136/ard.2010.140111

16. Shao Y, Chen F, Chen Y, Zhang W, Lin Y, Cai Y, Yin Z, Tao S, Liao Q, Zhao J, Mai H, He Y, He J, Cui L (2017) Association between genetic polymorphisms in the autophagy-related 5 gene promoter and the risk of sepsis. Sci Rep 7:9399. https://doi.org/ 10.1038/s41598-017-09978-5

17. Dezelak M, Repnik K, Koder S, Ferkolj I, Potocnik U (2016) A prospective pharmacogenomic study of Crohn's disease patients during routine therapy with anti-TNF-alpha drug adalimumab: contribution of ATG5, NFKB1, and CRP genes to pharmacodynamic variability. OMICS 20:296-309. https://doi.org/10.1089/ omi.2016.0005

18. Li M, Ma F, Wang J, Li Q, Zhang P, Yuan P, Luo Y, Cai R, Fan Y, Chen S, Li Q, Xu B (2018) Genetic polymorphisms of autophagyrelated gene 5 (ATG5) rs473543 predict different disease-free survivals of triple-negative breast cancer patients receiving anthracycline- and/or taxane-based adjuvant chemotherapy. Chin J Cancer 37:4. https://doi.org/10.1186/s40880-018-0268-1

19. Pyo JO, Yoo SM, Ahn HH, Nah J, Hong SH, Kam TI, Jung S, Jung YK (2013) Overexpression of Atg5 in mice activates autophagy and extends lifespan. Nat Commun 4:2300. https://doi.org/10. 1038/ncomms 3300
20. Taneike M, Yamaguchi O, Nakai A, Hikoso S, Takeda T, Mizote I, Oka T, Tamai T, Oyabu J, Murakawa T, Nishida K, Shimizu T, Hori M, Komuro I, Takuji Shirasawa TS, Mizushima N, Otsu K (2010) Inhibition of autophagy in the heart induces age-related cardiomyopathy. Autophagy 6:600-606. https://doi.org/10.4161/ auto.6.5.11947

21. Xie X, Bi HL, Lai S, Zhang YL, Li N, Cao HJ, Han L, Wang HX, Li HH (2019) The immunoproteasome catalytic beta5i subunit regulates cardiac hypertrophy by targeting the autophagy protein ATG5 for degradation. Sci Adv 5:eaau0495. https://doi.org/10. 1126/sciadv.aau0495

22. Heusch G, Botker HE, Przyklenk K, Redington A, Yellon D (2015) Remote ischemic conditioning. J Am Coll Cardiol 65:177195. https://doi.org/10.1016/j.jacc.2014.10.031

23. Munk K, Andersen NH, Schmidt MR, Nielsen SS, Terkelsen CJ, Sloth E, Botker HE, Nielsen TT, Poulsen SH (2010) Remote ischemic conditioning in patients with myocardial infarction treated with primary angioplasty: impact on left ventricular function assessed by comprehensive echocardiography and gated single-photon emission CT. Circ Cardiovasc Imaging 3:656-662. https://doi.org/10.1161/CIRCIMAGING.110.957340

24. Honda T, He Q, Wang F, Redington AN (2019) Acute and chronic remote ischemic conditioning attenuate septic cardiomyopathy, improve cardiac output, protect systemic organs, and improve mortality in a lipopolysaccharide-induced sepsis model. Basic Res Cardiol 114:15. https://doi.org/10.1007/s00395-019-0724-3

25. He Q, Wang F, Ryan TD, Chalasani M, Redington AN (2020) Repeated remote ischemic conditioning reduces doxorubicininduced cardiotoxicity. JJACC Cardio Oncol 2:41-52. https:// doi.org/10.1016/j.jaccao.2020.01.005\%

26. Rohailla S, Clarizia N, Sourour M, Sourour W, Gelber N, Wei C, Li J, Redington AN (2014) Acute, delayed and chronic remote ischemic conditioning is associated with downregulation of mTOR and enhanced autophagy signaling. PLoS ONE 9:e111291. https://doi.org/10.1371/journal.pone.0111291

27. Hausenloy DJ, Kharbanda RK, Moller UK, Ramlall M, Aaroe J, Butler R, Bulluck H, Clayton T, Dana A, Dodd M, Engstrom T, Evans R, Lassen JF, Christensen EF, Garcia-Ruiz JM, Gorog DA, Hjort J, Houghton RF, Ibanez B, Knight R, Lippert FK, Lonborg JT, Maeng M, Milasinovic D, More R, Nicholas JM, Jensen LO, Perkins A, Radovanovic N, Rakhit RD, Ravkilde J, Ryding AD, Schmidt MR, Riddervold IS, Sorensen HT, Stankovic G, Varma M, Webb I, Terkelsen CJ, Greenwood JP, Yellon DM, Botker HE, Investigators C-E-P (2019) Effect of remote ischaemic conditioning on clinical outcomes in patients with acute myocardial infarction (CONDI-2/ERIC-PPCI): a single-blind randomised controlled trial. Lancet 394:1415-1424. https://doi.org/10.1016/ S0140-6736(19)32039-2

28. Thielmann M, Kottenberg E, Kleinbongard P, Wendt D, Gedik N, Pasa S, Price V, Tsagakis K, Neuhauser M, Peters J, Jakob H, Heusch G (2013) Cardioprotective and prognostic effects of remote ischaemic preconditioning in patients undergoing coronary artery bypass surgery: a single-centre randomised, double-blind, controlled trial. Lancet 382:597-604. https://doi.org/10.1016/ S0140-6736(13)61450-6

29. Heusch G (2020) Myocardial ischaemia-reperfusion injury and cardioprotection in perspective. Nat Rev Cardiol 17:773-789. https://doi.org/10.1038/s41569-020-0403-y

30. Lieder HR, Irmert A, Kamler M, Heusch G, Kleinbongard P (2019) Sex is no determinant of cardioprotection by ischemic preconditioning in rats, but ischemic/reperfused tissue mass is for remote ischemic preconditioning. Physiol Rep. https://doi.org/ $10.14814 /$ phy2.14146

31. Galan-Arriola C, Villena-Gutierrez R, Higuero-Verdejo MI, Diaz-Rengifo IA, Pizarro G, Lopez GJ, Molina-Iracheta A, Perez-Martinez C, Garcia RD, Gonzalez-Calle D, Lobo M, 
Sanchez PL, Oliver E, Cordoba R, Fuster V, Sanchez-Gonzalez J, Ibanez B (2021) Remote ischaemic preconditioning ameliorates anthracycline-induced cardiotoxicity and preserves mitochondrial integrity. Cardiovasc Res 117:1132-1143. https://doi. org/10.1093/cvr/cvaa181

32. Gertz ZM, Cain C, Kraskauskas D, Devarakonda T, Mauro AG, Thompson J, Samidurai A, Chen Q, Gordon SW, Lesnefsky EJ, Das A, Salloum FN (2019) Remote ischemic pre-conditioning attenuates adverse cardiac remodeling and mortality following doxorubicin administration in mice. JACC Cardio Oncol 1:221-234. https://doi.org/10.1016/j.jaccao.2019.11.004

33. Hara T, Nakamura K, Matsui M, Yamamoto A, Nakahara Y, Suzuki-Migishima R, Yokoyama M, Mishima K, Saito I, Okano H, Mizushima N (2006) Suppression of basal autophagy in neural cells causes neurodegenerative disease in mice. Nature 441:885-889. https://doi.org/10.1038/nature04724

34. Sohal DS, Nghiem M, Crackower MA, Witt SA, Kimball TR, Tymitz KM, Penninger JM, Molkentin JD (2001) Temporally regulated and tissue-specific gene manipulations in the adult and embryonic heart using a tamoxifen-inducible Cre protein. Circ Res 89:20-25. https://doi.org/10.1161/hh1301.092687

35. Buerger A, Rozhitskaya O, Sherwood MC, Dorfman AL, Bisping E, Abel ED, Pu WT, Izumo S, Jay PY (2006) Dilated cardiomyopathy resulting from high-level myocardial expression of Cre-recombinase. J Card Fail 12:392-398. https://doi.org/10. 1016/j.cardfail.2006.03.002

36. Botker HE, Hausenloy D, Andreadou I, Antonucci S, Boengler K, Davidson SM, Deshwal S, Devaux Y, Di Lisa F, Di Sante M, Efentakis P, Femmino S, Garcia-Dorado D, Giricz Z, Ibanez B, Iliodromitis E, Kaludercic N, Kleinbongard P, Neuhauser M, Ovize M, Pagliaro P, Rahbek-Schmidt M, Ruiz-Meana M, Schluter KD, Schulz R, Skyschally A, Wilder C, Yellon DM, Ferdinandy P, Heusch G (2018) Practical guidelines for rigor and reproducibility in preclinical and clinical studies on cardioprotection. Basic Res Cardiol 113:39. https://doi.org/10.1007/ s00395-018-0696-8

37. Johnsen J, Pryds K, Salman R, Lofgren B, Kristiansen SB, Botker HE (2016) The remote ischemic preconditioning algorithm: effect of number of cycles, cycle duration and effector organ mass on efficacy of protection. Basic Res Cardiol 111:10. https://doi.org/ 10.1007/s00395-016-0529-6

38. He Q, Wang F, Honda T, James J, Li J, Redington A (2018) Loss of miR-144 signaling interrupts extracellular matrix remodeling after myocardial infarction leading to worsened cardiac function. Sci Rep 8:16886. https://doi.org/10.1038/s41598-018-35314-6

39. Klionsky DJ, Abdalla FC, Abeliovich H, Abraham RT, Acevedo-Arozena A, Adeli K, Agholme L, Agnello M, Agostinis P, Aguirre-Ghiso JA, Ahn HJ, Ait-Mohamed O, Ait-Si-Ali S, Akematsu T, Akira S, Al-Younes HM, Al-Zeer MA, Albert ML, Albin RL, Alegre-Abarrategui J, Aleo MF, Alirezaei M, Almasan A, Almonte-Becerril M, Amano A, Amaravadi R, Amarnath S, Amer AO, Andrieu-Abadie N, Anantharam V, Ann DK, AnoopkumarDukie S, Aoki H, Apostolova N, Arancia G, Aris JP, Asanuma K, Asare NY, Ashida H, Askanas V, Askew DS, Auberger P, Baba M, Backues SK, Baehrecke EH, Bahr BA, Bai XY, Bailly Y, Baiocchi R, Baldini G, Balduini W, Ballabio A, Bamber BA, Bampton ET, Banhegyi G, Bartholomew CR, Bassham DC, Bast RC Jr, Batoko H, Bay BH, Beau I, Bechet DM, Begley TJ, Behl C, Behrends C, Bekri S, Bellaire B, Bendall LJ, Benetti L, Berliocchi L, Bernardi H, Bernassola F, Besteiro S, Bhatia-Kissova I, Bi X, Biard-Piechaczyk M, Blum JS, Boise LH, Bonaldo P, Boone DL, Bornhauser BC, Bortoluci KR, Bossis I, Bost F, Bourquin JP, Boya P, Boyer-Guittaut M, Bozhkov PV, Brady NR, Brancolini C, Brech A, Brenman JE, Brennand A, Bresnick EH, Brest P, Bridges D, Bristol ML, Brookes PS, Brown EJ, Brumell JH et al (2012) Guidelines for the use and interpretation of assays for monitoring autophagy. Autophagy 8:445-544. https://doi.org/10.4161/auto. 19496

40. Zhang Y, Riesterer C, Ayrall AM, Sablitzky F, Littlewood TD, Reth M (1996) Inducible site-directed recombination in mouse embryonic stem cells. Nucleic Acids Res 24:543-548. https://doi. org/10.1093/nar/24.4.543

41. Chen K, Zeng J, Xiao H, Huang C, Hu J, Yao W, Yu G, Xiao W, Xu H, Ye Z (2016) Regulation of glucose metabolism by p62/ SQSTM1 through HIF1alpha. J Cell Sci 129:817-830. https://doi. org/10.1242/jcs. 178756

42. Duran A, Amanchy R, Linares JF, Joshi J, Abu-Baker S, Porollo A, Hansen M, Moscat J, Diaz-Meco MT (2011) p62 is a key regulator of nutrient sensing in the mTORC1 pathway. Mol Cell 44:134-146. https://doi.org/10.1016/j.molcel.2011.06.038

43. Sugiyama M, Yoshizumi T, Yoshida Y, Bekki Y, Matsumoto Y, Yoshiya S, Toshima T, Ikegami T, Itoh S, Harimoto N, Okano S, Soejima Y, Shirabe K, Maehara Y (2017) p62 Promotes amino acid sensitivity of mTOR pathway and hepatic differentiation in adult liver stem/progenitor cells. J Cell Physiol 232:2112-2124. https://doi.org/10.1002/jcp.25653

44. Ni HM, Chao X, Yang H, Deng F, Wang S, Bai Q, Qian H, Cui Y, Cui W, Shi Y, Zong WX, Wang Z, Yang L, Ding WX (2019) Dual roles of mammalian target of rapamycin in regulating liver injury and tumorigenesis in autophagy-defective mouse liver. Hepatology 70:2142-2155. https://doi.org/10.1002/hep.30770

45. Nakai A, Yamaguchi O, Takeda T, Higuchi Y, Hikoso S, Taniike M, Omiya S, Mizote I, Matsumura Y, Asahi M, Nishida K, Hori M, Mizushima N, Otsu K (2007) The role of autophagy in cardiomyocytes in the basal state and in response to hemodynamic stress. Nat Med 13:619-624. https://doi.org/10.1038/nm1574

46. Rehmani T, Salih M, Tuana BS (2019) Cardiac-specific cre induces age-dependent dilated cardiomyopathy (DCM) in mice. Molecules. https://doi.org/10.3390/molecules24061189

47. Billah M, Ridiandries A, Allahwala UK, Mudaliar H, Dona A, Hunyor S, Khachigian LM, Bhindi R (2020) Remote ischemic preconditioning induces cardioprotective autophagy and signals through the IL-6-dependent JAK-STAT pathway. Int J Mol Sci. https://doi.org/10.3390/ijms21051692

48. Wang Y, Shen J, Xiong X, Xu Y, Zhang H, Huang C, Tian Y, Jiao C, Wang X, Li X (2014) Remote ischemic preconditioning protects against liver ischemia-reperfusion injury via heme oxygenase-1-induced autophagy. PLoS ONE 9:e98834. https://doi. org/10.1371/journal.pone.0098834

49. Xie Y, Jiang D, Xiao J, Fu C, Zhang Z, Ye Z, Zhang X (2018) Ischemic preconditioning attenuates ischemia/reperfusioninduced kidney injury by activating autophagy via the SGK1 signaling pathway. Cell Death Dis 9:338. https://doi.org/10.1038/ s41419-018-0358-7

50. Sciarretta S, Yee D, Nagarajan N, Bianchi F, Saito T, Valenti V, Tong M, Del Re DP, Vecchione C, Schirone L, Forte M, Rubattu S, Shirakabe A, Boppana VS, Volpe M, Frati G, Zhai P, Sadoshima J (2018) Trehalose-induced activation of autophagy improves cardiac remodeling after myocardial infarction. J Am Coll Cardiol 71:1999-2010. https://doi.org/10.1016/j.jacc.2018. 02.066

51. Wei M, Xin P, Li S, Tao J, Li Y, Li J, Liu M, Li J, Zhu W, Redington AN (2011) Repeated remote ischemic postconditioning protects against adverse left ventricular remodeling and improves survival in a rat model of myocardial infarction. Circ Res 108:1220-1225. https://doi.org/10.1161/CIRCRESAHA.110. 236190

52. Dutta S, Sengupta $P(2016)$ Men and mice: relating their ages. Life Sci 152:244-248. https://doi.org/10.1016/j.lfs.2015.10.025

53. Heinen A, Behmenburg F, Aytulun A, Dierkes M, Zerbin L, Kaisers W, Schaefer M, Meyer-Treschan T, Feit S, Bauer I, Hollmann MW, Huhn R (2018) The release of cardioprotective humoral 
factors after remote ischemic preconditioning in humans is ageand sex-dependent. J Transl Med 16:112. https://doi.org/10.1186/ s12967-018-1480-0

54. Tyagi S, Singh N, Virdi JK, Jaggi AS (2019) Diabetes abolish cardioprotective effects of remote ischemic conditioning: evidences and possible mechanisms. J Physiol Biochem 75:19-28. https:// doi.org/10.1007/s13105-019-00664-w

55. Kleinbongard P, Botker HE, Ovize M, Hausenloy DJ, Heusch G (2020) Co-morbidities and co-medications as confounders of cardioprotection - does it matter in the clinical setting? Br J Pharmacol 177:5252-5269. https://doi.org/10.1111/bph.14839
56. Whittaker P, Przyklenk K (2014) From ischemic conditioning to 'hyperconditioning': clinical phenomenon and basic science opportunity. Dose-Response 12:650-663. https://doi.org/10.2203/ dose-response.14-035. Whittaker

57. Turcato S, Turnbull L, Wang GY, Honbo N, Simpson PC, Karliner JS, Baker AJ (2006) Ischemic preconditioning depends on age and gender. Basic Res Cardiol 101:235-243. https://doi.org/10.1007/ s00395-006-0585-4 